\title{
Towards an Understanding of the Role of Standard Setters in Standard Setting
}

\section{Citation}

Allen, Abigail M., and Karthik Ramanna. "Towards an Understanding of the Role of Standard Setters in Standard Setting." Journal of Accounting \& Economics 55, no. 1 (February 2013).

\section{Published Version}

http://dx.doi.org/10.1016/j.jacceco.2012.05.003

\section{Permanent link}

http://nrs.harvard.edu/urn-3:HUL.InstRepos:11320611

\section{Terms of Use}

This article was downloaded from Harvard University's DASH repository, and is made available under the terms and conditions applicable to Open Access Policy Articles, as set forth at http:// nrs.harvard.edu/urn-3:HUL.InstRepos:dash.current.terms-of-use\#OAP

\section{Share Your Story}

The Harvard community has made this article openly available.

Please share how this access benefits you. Submit a story.

Accessibility 
H A R VAR D

\title{
Towards an understanding of the role of standard setters in standard setting
}

\author{
Abigail Allen \\ Karthik Ramanna
}

\section{Working Paper}

10-105

May 24, 2012 


\title{
Towards an understanding of the role of standard setters in standard setting*
}

\author{
Abigail Allen and Karthik Ramanna \\ Harvard Business School
}

First draft: May 21, 2010

This draft: May 24, 2012

\begin{abstract}
We investigate the effect of standard setters in standard setting: We examine how certain professional and political characteristics of FASB members and SEC commissioners predict the accounting "reliability" and "relevance" of proposed standards. Notably, we find FASB members with backgrounds in financial services are more likely to propose standards that decrease "reliability" and increase "relevance," partly due to their tendency to propose fair-value methods. We find opposite results for FASB members affiliated with the Democratic Party, although only when excluding financial-services background as an independent variable. Jackknife procedures show that results are robust to omitting any individual standard setter.
\end{abstract}

\footnotetext{
${ }^{*}$ We thank Mary Barth, Robert Bloomfield (the reviewer), Michelle Hanlon (the editor), Paul Healy, S.P. Kothari, Krishna Palepu, Sugata Roychowdhury, Doug Skinner, Ross Watts, and seminar participants at Minnesota, MIT, the 2010 HBS IMO Conference, and the 2011 AAA FARS Conference for helpful comments; Beiting Cheng, Michael Kregar, Scott Renner, and the HBS division of research for excellent research assistance; and Charry Boris, Ron Guerrette, and the FAF for generous help with sourcing data on comment letters and exposure drafts. Any errors are our responsibility.
} 


\section{Introduction}

As the Financial Accounting Standards Board (FASB) closes in on four decades, the role of its standards in shaping U.S. and international corporate reporting is widely acknowledged. An empirical literature on the political economy of FASB standard setting has emerged over that period to explore the origins of accounting standards largely through an analysis of constituent comment-letter lobbying (e.g., Watts and Zimmerman, 1978). But such comment-letter lobbying is only part of the political economy that determines accounting standards (e.g., Ramanna, 2008, studies the role of congressional intervention). At the core of the standard-setting process are the individuals that comprise the FASB and its sanctioning authority, the Securities and Exchange Commission (SEC). In this paper, we develop and test some exploratory hypotheses with a view towards building an understanding of the role of FASB and SEC regulators in U.S. GAAP.

Although the idea that FASB and SEC regulators can matter in standard setting is intuitively appealing, it has not been subject to empirical testing. This is due in part to limited data availability, but also in part to neoclassical economics, which is widely used in accounting research and tends to view "individuals" as "so empirically unimportant as to allow the use of Occam's razor in positive models" (e.g., Kalt and Zupan, 1984, p. 279). Recently, however, empiricists in finance and accounting have begun exploring the role of individuals on equilibrium outcomes, particularly in the context of individual managers and firm policies (e.g., Bertrand and Schoar, 2003; Bamber, Jiang, and Wang, 2010; Dyreng, Hanlon, and Maydew, 2010). Moreover, in the regulation literature itself, there is some evidence of regulators' preferences mattering in outcomes at both the congressional (e.g., Kau and Rubin, 1979) and the bureaucratic agency levels (e.g., Gormley, 1979). Thus, in the context of accounting standard 
setting, tests of influence of FASB and SEC regulators can help refine our understanding of the political economy of U.S. GAAP.

We conduct our study through an analysis of FASB exposure drafts proposed from 1973 (the FASB's inception) through 2007. There are 149 such exposure drafts in our sample after data limitations. Our primary tests involve regressing assessments of the nature of an exposure draft on the average background characteristics of extant FASB and SEC regulators.

We evaluate a proposed SFAS (Statement of Financial Accounting Standards) by focusing in particular on its impact on accounting "relevance" and "reliability"- two characteristics usually cited as fundamental accounting properties in accounting textbooks (e.g., Stickney, Weil, Schipper, and Francis, 2010, pp. 23, 114). There are no obvious metrics to use in evaluating exposure drafts; our choice of "relevance" and "reliability" reflects our judgment on their importance to accounting. Since at least the publication of its conceptual statements in the late 1970s (e.g., FASB, 1978; 1980), the FASB itself has viewed "relevance" and "reliability" as "the two primary qualities that make accounting information useful for decision making" (FASB, 1980, p. 5), adding that "serious disagreement" often arises "about whether the superior relevance of the results of one [accounting] method outweighs the superior reliability of the results of [another]" (FASB, 1980, p. 8). Moreover, the increased prominence, since the mid1990s, of fair-value accounting in standard setting has generated additional interest in the "tradeoff" between "relevance" and "reliability." The FASB has often justified the increased use of fair values by arguing it will increase the "relevance" of accounting numbers (e.g., Johnson, 2005). In contrast, some academics have argued accounting estimates generated under fair-value accounting will decrease the "reliability" of financial reports (e.g., Watts, 2003). ${ }^{1}$

\footnotetext{
${ }^{1}$ While "reliability" and "relevance" can be trade-offs in some circumstances, it is an empirical question as to whether these concepts are always at odds with each other.
} 
To obtain assessments of exposure drafts' impact on "relevance" and "reliability" that are independent of researcher judgment, we develop a measure based on comment letters filed by the Big 8/6/5/4 auditors (hereafter, "Big $\mathrm{N}$ auditors"). There are 908 such comment letters in our sample after data limitations. The advantage to using Big $\mathrm{N}$ auditors' comment letters is that they are available on most exposure drafts in our sample period and are contemporaneous (i.e., no hindsight bias). The letters are, however, likely to reflect the auditors' private incentives, which can confound inferences if endogenous to our explanatory variables (i.e., the characteristics of FASB and SEC regulators). To mitigate this concern, in robustness tests we use an alternative assessment of the exposure drafts from two seasoned research assistants (with over thirty years of combined experience in accounting) blind to the objective of this study.

We build a biographical database of all 39 FASB members and all 41 SEC commissioners serving between 1973 and 2007. Drawing on empirical political-economy research that has examined the characteristics of regulators on regulation (see Dal Bo, 2006, for a review), we focus on two sets of characteristics: professional and political. The professional characteristics are length of regulatory tenure, industry background in auditing, and industry background in investment banking/ investment management (hereafter, "financial services"); ${ }^{2}$ the political characteristics are affiliations, if any, with the Democratic and Republican parties. Prior research has consistently found high correlations between regulators' professional and political characteristics and so has examined these characteristics both independently and jointly in multivariate regressions. We adopt this approach in our empirical design.

In examining professional characteristics independently, we find that longer average FASB and SEC tenures are associated with exposure drafts perceived by auditors as decreasing

\footnotetext{
${ }^{2}$ When studying industry background, the regulatory literature has focused on industries most closely associated with the regulations being studied. In our setting, we focus on auditing and financial services, viewing them as frontline intermediaries in the production and use of accounting information.
} 
accounting "reliability;" but, we find no evidence of an association between the regulators' tenures and exposure drafts" "relevance." If decreased "reliability" is an undesirable property of accounting (e.g., Watts, 2003), the result is consistent with longer regulatory tenures compromising accounting quality. ${ }^{3}$ Concerning industry backgrounds, we expect regulators with prior employment in auditing to be more sympathetic to accounting "reliability" (since "reliable" accounting lowers auditors' litigation risk; e.g., Watts, 2003); in contrast, we expect members with prior employment in financial services to be sympathetic to valuation-relevant accounting (e.g., ICI, 2008), and thus more likely to promote "relevance" at the expense of "reliability" (e.g., Johnson, 2005). We do not find results associating regulators' careers in auditing with "reliability" and "relevance." However, we find evidence that exposure drafts proposed by FASB members and SEC commissioners with prior experience in financial services are viewed by the Big N auditors as decreasing accounting "reliability." Further, in the case of FASB members, experience in financial services is associated with exposure drafts viewed by the Big $\mathrm{N}$ auditors as increasing accounting "relevance." Additional analysis suggests these associations are partly due to the tendency of FASB members with financial-services backgrounds (the proportion of which increases in our sample period) to propose standards that use fair-value methods.

In studying regulators' political characteristics, we are motivated by prior politicalscience research that has shown that political affiliations are salient predictors of regulator behavior: e.g., Cohen (1986) provides evidence that Democratic regulators are on average less sympathetic to corporate interests. In examining political characteristics independently, we find evidence that increased proportional membership of Democrats on the FASB is associated with exposure drafts that are perceived by the Big $\mathrm{N}$ auditors as both increasing accounting

\footnotetext{
${ }^{3}$ Stigler (1971) argues that longer regulatory tenures compromise regulation by promoting greater "coziness" between regulators and the regulated.
} 
"reliability" and decreasing accounting "relevance." However, when we examine the regulators' professional and political characteristics jointly, we find that the results on backgrounds in financial services alone survive. Thus, in our population and time period, political affiliation does not appear to be a significant factor beyond financial services affiliation. We note that there is no ex-ante theory that suggests either professional or political characteristics are more important than the other in explaining regulatory decisions (e.g., Dal Bo, 2006), thus future research is needed to draw more definitive conclusions.

There are certain other caveats to our analysis. First, the small population of regulators in our study might mean that influential observations are driving reported statistical significance. We mitigate this concern through a jackknifing procedure where we re-estimate all regressions successively eliminating each regulator to determine if she/he is instrumental to inferences: this procedure does not alter inferences on variables discussed as statistically significant. Second, the scope of our study is limited by our choice of dependent and independent variables: other dependent variables (e.g., "comparability," compliance costs, net-income effect) and independent variables (e.g., age, gender, education) can be considered. Thus, our findings should be interpreted as the result of a first look at the relationship between standard setters and GAAP.

These caveats notwithstanding, the results described above are robust to numerous substantive and econometric controls, including controls for cross-sectional dependence of observations, auditor-specific effects, and aggregate market conditions. Additionally, we conduct a number of sensitivity tests, including (i) using research assistants' (instead of the Big $\mathrm{N}$ auditors') evaluations of exposure drafts; (ii) assigning greater weight to FASB and SEC chairmen when calculating the average background characteristics of extant regulators (to assess if chairmen are more important in standard setting); and (iii) restricting our analysis to periods of 
economic growth (to assess the sensitivity of our findings to broader macroeconomic conditions). These results are discussed in Section 5.

Broadly, the evidence in this paper suggests individual standard setters have equilibrium effects on standard setting. Kothari, Ramanna, and Skinner (2010) summarize two theories to explain accounting standard setting: "capture" and "ideology." Under capture theory, constituent lobbying determines standard-setting outcomes since regulators are "captured" by their specialinterest constituents; under ideology theory, constituent lobbying is only one input to standard setting, which is also influenced by regulators' ideologies. If accounting standard setting is more aptly described by ideology theory, one would expect to see the systematic impact of regulators' characteristics in accounting standards, as we find. However, empirically it is difficult to rule out "capture" because the selection of regulators is itself a political process, which may be beholden to special interests. For example, our findings associating the growing proportion of FASB members from financial services to fair-value standards can be explained by the growth of the financial-services sector over our sample period: changing political economies associated with the growth of finance may have resulted in the increased proportion of finance-industry veterans on the FASB, who in turn proposed fair-value standards. Going forward, a research program in this area that draws on our initial look at the question can provide additional insights into the role of individual regulators and special-interest politics on the nature of accounting regulation.

The rest of the paper is organized as follows. Section 2 lays out the motivation for our research-design choices and discusses associated limitations. Section 3 describes the construction of variables and develops associated hypotheses. Section 4 discusses descriptive statistics and the multivariate regression strategy. Section 5 presents and interprets the multivariate results, including robustness tests. Section 6 concludes. 


\section{Motivating research-design choices}

\subsection{Which dependent variables?}

To empirically assess the role of standard setters in standard setting, we require a reasonable and parsimonious metric to evaluate proposed standards. The analogous literature that explores the role of individual managers in firm policies generally employs explicit performance and governance metrics such as earnings, stock returns, disclosure standards, and accounting quality. ${ }^{4}$ Such obvious metrics are not applicable to our setting. In evaluating standards, we use "reliability" and "relevance" as discussed above. "Reliability" and "relevance" are widely viewed as being among accounting's "fundamental qualitative characteristics" by both academics (e.g., Stickney et al., 2010, p. 765; Dyckman, Magee, and Pfeiffer, 2011) and the FASB (e.g., FASB, 1978; 1980). ${ }^{5,6}$ In addition to "reliability" and "relevance," there are likely other possible metrics to evaluate accounting standards, including "comparability," "consistency," and whether the standards are income increasing. In this sense, there is considerable scope for additional research along the lines we have pursued.

\subsection{Which independent variables?}

In selecting the characteristics of FASB members and SEC commissioners to study, we are motivated by prior political-economy research in this area. Dal Bo (2006), in a recent review,

\footnotetext{
${ }^{4}$ See, for example, Bamber et al. (2010); Dyreng et al. (2010); and Ge, Matsumoto, and Zhang (2011).

${ }^{5}$ The classification of standards as along "reliability" and "relevance" can also be related to research on the demands of debtholders versus equityholders on financial reporting practices. Debtholders are usually seen as demanding "reliability" (e.g., Watts, 2003), while equityholders are seen as demanding either "relevance" (e.g., Barth, 2006) or both "reliability" and "relevance" (e.g., LaFond and Watts, 2008).

${ }^{6}$ Recently, the FASB modified its conceptual framework to move away from "reliability" towards "representational faithfulness." This change was likely made (at least in part) due to criticisms that the FASB was undermining the "reliability" of accounting standards (e.g., Watts, 2003). In response to these criticisms, some FASB members argued that "reliability" had been "misunderstood" to mean "verifiability;" the concept of "representational faithfulness" was advanced to replace "reliability" (e.g., Schipper, 2005). The change was proposed at a joint FASBIASB board meeting on May 25, 2005, and the change was introduced into the conceptual framework in 2010. Since the change was initiated towards the end of our sample period, and went into effect after our sample period, we use "reliability," not "representational faithfulness," in our analyses.
} 
notes that empirical research on the role of regulators in regulation, while (p. 215) "well short of abundant," has largely focused on regulators' professional characteristics_particularly, industry backgrounds_-and regulators' political party affiliation. In addition, he points to empirical work on the role of regulators' terms-in-office on regulatory outcomes. Given the exploratory nature of our study, we focus on these independent variables.

On industry backgrounds, ex ante, we have a broad choice of industry classifications to organize the data (e.g., SIC codes). However, given the limited number of FASB members $(n=39)$ and SEC commissioners $(n=41)$ in our sample period, we are unable to use such broadbased industry classifications. Prior empirical research on regulators' industry backgrounds has focused on industries most closely associated with those regulations (e.g., Cohen, 1986, studies whether Federal Communications Commission, FCC, regulators with broadcasting industry experience are more supportive of that industry). In our case of studying accounting standard setting, we identify auditing and financial services as the most closely associated industries. We focus on backgrounds in auditing because accounting and auditing are joint products in financial reporting and because of the historical evidence on the close input of the audit industry in standard setting (e.g., Watts and Zimmerman, 1982, 1983). We focus on backgrounds in financial services because the financial services industry is a front-line intermediary in using accounting information. This includes investment management, which uses accounting information on the buy side, and investment banking, which uses accounting information on the sell-side. Thus, we expect an investigation of standard setters with backgrounds in auditing and financial services to provide a useful lens into standard setting. ${ }^{7}$

\footnotetext{
${ }^{7}$ In addition to tenure lengths, industry backgrounds, and party affiliation, it is possible that other characteristics of FASB and SEC regulators also matter. For example, in the context of studying the idiosyncratic styles of CEOs, Bertrand and Schoar (2003) examine whether managers' age, gender, and education matter. In unreported tests, we examine whether such characteristics of FASB and SEC regulators are systematically associated with the standards
} 


\subsection{Limitations of the research design}

We attempt to provide some empirical evidence on the role of standard setters in standard setting. Such evidence can complement existing findings on the role of constituent commentletter lobbying and congressional intervention in standard setting (see Kothari et al., 2010, for a recent review). Empirically, we focus on the association between standard setters and the exposure drafts they propose. Exposure drafts appear prior to direct comment-letter lobbying and thus provide a relatively clean setting (relative to final standards) to examine the role of standard setters. Of course, constituent lobbying can influence the exposure draft process as well, but such ex-ante lobbying is difficult to observe, and our research design does not address its possible effects on standard setting. Further, it is possible that the selection of regulators to the FASB and SEC is itself a function of constituent lobbying. Such lobbying, in turn, is likely driven by extant economic and political circumstances, for example, macroeconomic conditions, globalization (e.g., growth of IFRS), the rise of the financial services sector, or the rise of information technologies. ${ }^{8}$ While our research design allows us to infer a role for standard setters in standard setting, it does not allow us to conclusively establish whether this role derives from some intrinsic ideology of regulators or from prevailing political economies.

\section{Variable measurement and hypotheses}

\subsection{Dependent variables: decreased "reliability" and increased "relevance"}

To evaluate the FASB exposure drafts in our sample period independently of researcher judgment, we rely on two separate methods. First, we examine relevant comment letters filed by

they propose. We also test whether the regulators' backgrounds in academia and government systematically vary with their proposals. The results are inconclusive.

${ }^{8}$ On the role of macroeconomics on regulation, Bertomeu and Magee (2011) propose a model where accounting regulators are subject to different political pressures during different stages of the economic cycle. 
the Big N auditors. Second, we use two research assistants who are blind to the objectives of the study to manually assess the exposure drafts (this process is described later in the sub-section).

The key advantage to using Big $\mathrm{N}$ auditors' comment letters is that they provide a consistent and contemporaneous source of exposure-draft evaluations. The evaluations are consistent in that the Big $\mathrm{N}$ auditors comment on a large majority of exposure drafts in our sample period, so we do not have to rely on evaluations from disparate sources. The evaluations are contemporaneous in that the letters do not suffer from hindsight bias. Moreover, Big $\mathrm{N}$ auditors are sophisticated consumers of accounting standards, so we expect their evaluations to have information content.

The changing industrial organization of the U.S. auditing oligopoly means that our set of "Big N auditors" begins with the "Big 8" in 1973 and ends with the "Big 4" in 2007. Table 1 provides a timeline of the changing dynamics of the U.S. audit industry. There are 170 distinct FASB exposure drafts that became 163 distinct SFAS in our sample period, 1973-2007. The absence of Big $\mathrm{N}$ auditor comments letters on six SFAS over that period decreases our sample size to 157 SFAS (Table 1 provides details on the SFAS without comment letters). These 157 SFAS can be traced back to 149 distinct exposure drafts (several exposure drafts resulted in multiple SFAS). There are collectively 908 unique comment letters by the Big $\mathrm{N}$ auditors on the 149 exposure drafts. We obtain paper copies of these comment letters from the FASB archives in Norwalk, Connecticut, and then digitize the comment letters using a combination of optical character recognition software and manual transcription. The digitized letters are then analyzed for contextually relevant occurrences of word stems "relevan" and "reliab" to create our auditorbased measures of the exposure drafts' impact on decreased "reliability" and increased "relevance" using a process described in Appendix A. Based on that process, we define two 
variables, inc_relv and dec_relb, intended to capture the intensity of auditors' concerns that a proposed standard will increase "relevance" and decrease "reliability," respectively. The variables inc_relv and dec_relb are defined as follows. For each Big $\mathrm{N}$ auditor comment letter "i” on a proposed SFAS “ $j ":$

$$
\begin{aligned}
& i n c_{-} r e l v_{i j}=1-\frac{W C_{-} i n c_{-} r e l v_{i j}}{W C_{i j}} \\
& \text { dec_relb } b_{i j}=1-\frac{W C_{-} d e c_{-} r e l b_{i j}}{W C_{i j}}
\end{aligned}
$$

In the above equations, $W C_{-} i n c_{-} r e l v_{i j}$ is the word count of the first instance of the word stem "relevan" used in the context of increased "relevance" in comment letter " $i$ " on proposed SFAS “ $j ;$;" $W C_{-} d e c \_r e l b_{i j}$ is the word count of the first instance of the word stem "reliab" used in the context of decreased "reliability" in comment letter " $i$ " on proposed SFAS " $j$;" $W C_{i j}$ is the total word count of comment letter " $i$ " on proposed SFAS " $j$." In measuring inc_relv and dec_relb, we focus on the relative positions of the word stems "relevan" and "reliab" within a comment letter in order to get a measure of the relative importance of the auditors' sentiments on "relevance" and "reliability." The implicit assumption is that the stronger an auditor feels on "relevance" or "reliability," the earlier the concept will be discussed in the comment letter. ${ }^{9}$ By construction, inc_relv and dec_relb are confined to the range $[0,1]$ and are expected to increase in the strength of an auditor's opinion of an exposure draft's impact on increased "relevance" and decreased "reliability," respectively.

\footnotetext{
${ }^{9}$ This assumption is consistent with the usual format of comment letters, which generally begin with an introductory paragraph highlighting key issues before tackling technical details in the body of the letter. Thus, if "relevance" and "reliability" are sufficiently important concerns for a letter writer, we expect the terms to be mentioned in the introductory paragraph, resulting in higher scores on inc_relv and dec_relb. In untabulated analysis, we tested the robustness of our results to this assumption by defining alternative binary dependent variables that are not sensitive to the relative location of substantive references to "relevance" and "reliability." Results of this analysis are inconsistent with the concern that location-based construction may be driving our primary results.
} 
The Big $\mathrm{N}$ auditors' evaluations of exposure drafts are likely to be influenced by their private incentives: for example, if auditors are biased towards identifying decreased "reliability" over increased "relevance" because of litigation concerns, or if auditors are biased by the extant composition of their client base. ${ }^{10}$ In our tests, we do not expect these incentives to be correlated with our independent variables (i.e., the characteristics of FASB and SEC regulators), thus we expect these biases to add a scalar or a random variable to the regressand. Nevertheless, to mitigate the concern that auditor incentives can affect inferences in our tests, we supplement our auditor-based evaluations of the FASB exposure drafts with manual assessments by two research assistants who are blind to the objectives of the study but have extensive experience and practical familiarity with accounting. We use the standard dual-coder model in having the research assistants evaluate the exposure drafts. That is, the research assistants first independently evaluate each exposure draft based on a rubric discussed in Appendix B; then, the research assistants meet to resolve, if possible, instances of disagreement in their assessments. Of the 170 exposure drafts that became the 163 SFAS in our sample period, we are able to obtain, from the FASB archives, copies of 145 exposure drafts representing 137 distinct SFAS. Copies of the remaining exposure drafts, all dating from the 1980s and before, are not readily available in the FASB archive. ${ }^{11}$ The 145 exposure drafts are manually assessed and then merged with the 149 exposure drafts for which we have auditor-based evaluations, yielding a common sample of 126 exposure drafts. In the subsequent section, we explore the correlation in our dependent variables across the auditor and research-assistant evaluations. The research assistants' evaluations of

\footnotetext{
${ }^{10}$ Nelson, Elliott, and Tarpley (2002) provide some survey-based evidence on auditors' incentives.

${ }^{11}$ In the case of several exposure drafts from the 1980s and before, only one paper copy exists at the FASB archive. The FASB publications department is in the process of digitizing all historic records, but the exposure drafts missing from our study were not available at the time we conducted the analysis.
} 
decreased "reliability" and increased "relevance" are denoted Manual_dec_relb and Manual_inc_relv, respectively.

\subsection{Independent variables: characteristics of FASB members and SEC commissioners}

As noted earlier, our primary tests focus on the professional characteristics (i.e., tenure lengths and industry backgrounds) and political characteristics (i.e., party affiliations) of FASB members and SEC commissioners, because prior literature has studied these variables in the context of other regulators (e.g., Gormley, 1979; Cohen, 1986; Dal Bo, 2006, Leaver, 2009). The first FASB members took office in 1973 (shortly after the FASB's founding), and there have been 39 members on the board through December 2007. For each of these 39 members, we collect data on their length of tenure on the FASB, their backgrounds, if any, in auditing and financial services, and their political affiliations. In the same period, there have been 41 SEC commissioners, and we collect similar data on the commissioners.

Data on the duration of service on the board and the most recent employer prior to appointment to the board for FASB members are obtained primarily from two sources: (1) press notices issued by the FASB at a member's initial appointment; and (2) the FASB's annual informational bulletin, "Facts about FASB." We create two non-exhaustive indicator variables to classify the members' pre-FASB employers for further analysis: the first variable identifies whether a member worked for an audit firm prior to joining the board; the second whether the member worked for an investment bank or investment management firm. The equivalent data on the SEC commissioners' tenure and professional background are obtained from the SEC's historical archives, as well as from newspaper biographies of the commissioners (usually published upon the commissioners' initial appointment). 
In addition, we also build a database of the 39 FASB members' political affiliations. Conceptually, we are interested in whether the members identify as Democrats or Republicans. Since members of the FASB are not explicit political appointees (they are appointed by the nongovernmental Financial Accounting Foundation), the members' party affiliations are not readily known. Thus, we infer members' political identities by studying the history of their campaign contributions (if any). The Federal Election Commission (FEC) archives data on campaign contributions over $\$ 200$ by U.S. individuals. Members contributing to the Democratic Party are coded as Democrats; those contributing to the Republican Party are coded Republicans; while members not contributing to either party are not assigned a political identity. ${ }^{12}$ In the case of SEC commissioners, party affiliations are declared at or prior to appointment, so political identities need not be inferred from campaign contributions.

Our empirical tests are concerned with evaluating the influence of FASB and SEC regulators on exposure drafts. Accordingly, for each exposure draft in our sample, we average the personal characteristics of all FASB members and SEC commissioners in office at the time. For example, for the exposure draft that became SFAS 106, we average across the seven FASB members and five SEC commissioners in office as of February 1989 (the date the exposure draft was issued) their lengths of service on the board (hereafter, Tenure FASB and Tenure SEC, respectively). Similarly, we compute across the members and commissioners, the proportion with prior employment in auditing (hereafter, \% Auditor FASB and \% Auditor SEC, respectively), the proportion with prior employment in investment banking/ investment management (hereafter, \% Financial FASB and \% Financial SEC, respectively), the proportion contributing to the Democratic Party (hereafter, \% Dem Donor FASB and \% Democrat SEC,

\footnotetext{
${ }^{12}$ To the extent that the FEC database is not comprehensive, our measure of political contributions is measured with error. However, we are not aware of any reason for the FEC excluding contributors over \$200.
} 
respectively). We also compute the proportion of FASB members contributing to the Republican Party (hereafter, \% Rep Donor FASB). An equivalent variable for SEC commissioners is obviated by the fact that the proportion of Republicans and Democrats in the SEC sample is collectively exhaustive. In subsequent empirical tests, we do not include \% Auditor SEC because only one of the 41 SEC commissioners that served during our sample period worked for an audit firm prior to appointment to the commission.

The assumption implicit in averaging FASB members' and SEC commissioners' characteristics by exposure draft is that these documents represent the average position of the members and commissioners, respectively, in office at the time. ${ }^{13}$ In sensitivity tests described later, we examine the robustness of our results to assigning greater weight to FASB and SEC chairmen when calculating the average background characteristics.

\subsection{Hypotheses development}

Tenure FASB and Tenure SEC can be used to assess the impact of the average length of standard-setters' terms on regulatory capture. In the classical economic theory of regulation (Stigler, 1971), longer terms (i.e., higher values of Tenure FASB and Tenure SEC) signify greater "coziness" between regulators and the regulated, compromising regulatory outcomes. However, Leaver (2009) develops and tests a model of regulation where longer terms insulate regulators from political pressure, thus improving regulatory outcomes. If decreased "reliability" is an undesirable accounting property, a positive association between Tenure FASB/Tenure SEC and our proxies for decreased "reliability" (i.e., dec_relb and Manual_dec_relb) is consistent with longer term-lengths compromising regulatory outcomes per Stigler's theory. Similarly, if

\footnotetext{
${ }^{13}$ The maximum number of FASB members (SEC commissioners) at any given time during our sample period is seven (five). However, because new members do not immediately take office upon the resignation of another member, the size of the board can on occasion be less than seven (five).
} 
increased "relevance" augments accounting, a negative association between Tenure FASB/Tenure SEC and our proxies for increased "relevance" (i.e., inc_relv and Manual_inc_relv) is consistent with Stigler's theory.

$\%$ Auditor FASB, \% Financial FASB, and \% Financial SEC can be used to assess the impact of FASB members' and SEC commissioners' industry backgrounds on accounting standard setting. Prior research in political science has shown that regulators tend to be more supportive of the industries they hail from (perhaps because they seek employment or consulting opportunities in those industries upon completion of their regulatory terms, e.g., Cohen, 1986). Given their role in assuring financial reports, and the substantial legal liability associated with this role (e.g., Kellogg, 1984; Watts, 2003), we expect auditors, ex ante, to be more sympathetic to standards promoting "reliability" at the expense of "relevance." Moreover, if accounting regulators' industry backgrounds matter in standard setting, FASB members and SEC commissioners with backgrounds in auditing will, ceteris paribus, be more likely associated with standards promoting "reliability" (potentially over "relevance"). Thus, we predict negative coefficients between \% Auditor FASB and our proxies for both decreased "reliability" and increased "relevance." In contrast, ceteris paribus, we expect FASB members and SEC commissioners with backgrounds in financial services (defined as investment banking and investment management) to be more supportive of standards expected to improve accounting's relevance through the use of fair values. ${ }^{14}$ Moreover, if the FASB is correct about its arguments linking fair values to increased "relevance" and, sometimes, decreased "reliability" (Johnson, 2005), regulatory backgrounds in financial services are likely to result in standards with such

\footnotetext{
${ }^{14}$ Anecdotal evidence is consistent with this conjecture: e.g., the Investment Company Institute, the U.S. industry association for investment management firms, has strongly supported the use of fair-value accounting (ICI, 2008). Further, the Big 3 investment banks - Goldman Sachs, Morgan Stanley, and Merrill Lynch — were all enthusiastic supporters of fair-value-based rules for mergers and acquisitions, including in subsequent goodwill impairment testing, during the standard-setting process for SFAS 141 and 142 (e.g., Ramanna, 2006).
} 
properties. Thus, we predict positive coefficients between \% Financial FASB/\% Financial SEC and our proxies for both increased "relevance" and decreased "reliability."

The empirical literature in political science has also considered the implications of regulators' political affiliations on regulations, finding that Democratic regulators are on average less sympathetic to regulations benefiting corporate interests (Dal Bo, 2006). Extending this finding to accounting regulations, we can expect Democratic FASB and SEC regulators to be more sympathetic to standards that mitigate corporations' information advantage over outsiders. Evidence that corporations' information advantage benefits managers, e.g., Healy and Whalen (1999), is germane to this prediction. Such benefits can engender anti-corporate sentiment (e.g., a perception that managers exploit information advantages to receive "excess compensation") that is more likely to resonate with Democrats. Linking Democrats' relative focus on mitigating corporations' information advantage to promoting "reliability" over "relevance" is trickier. On the one hand, increased "reliability" over "relevance" can mitigate corporations' information asymmetry over outsiders because: (1) ceteris paribus, managers are inherently more likely to emphasize good news over bad news (e.g., Kothari, Shu, Wysocki, 2009); (2) regulatory solutions that are focused on mitigating corporations' information advantage emphasize, on average, timely discussion of bad news (e.g., Watts, 2003); and (3) such solutions—conservatism and verifiability—result in greater "reliability" over "relevance" (e.g., Kothari et al., 2010, p. 256). On the other hand, firms themselves have incentives to prefer "reliability" to "relevance," for example, corporations can benefit from accounting conservatism (e.g., through lower capital costs; LaFond and Watts, 2008; Zhang, 2008). Thus, the equilibrium relation between $\%$ Dem Donor FASB/ \% Democrat SEC and our proxies for increased "relevance"/ decreased "reliability" is an empirical question. Ex ante, we have no prediction on \% Rep Donor FASB. 
Nevertheless, we include this variable in our analysis because \% Dem Donor FASB and \% Rep

Donor FASB are not collectively exhaustive, and an analysis with \% Rep Donor FASB can provide additional insights. ${ }^{15}$

\section{Descriptive statistics and multivariate research design}

\subsection{Descriptive statistics}

Appendix C provides a summary definition of all variables in the study. Table 2, Panel A, reports summary statistics for our measures of decreased "reliability" (dec_relb and Manual_dec_relb) and increased "relevance" (inc_relv and Manual_inc_relv). The commentletter-based statistics are for the 908 Big $\mathrm{N}$ auditor comment letters, and the manually assessed statistics are for the 145 exposure drafts examined by our research assistants. The mean value of dec_relb (Manual_dec_relb) is $0.07(0.31)$ and the median value is zero (zero). There is considerable variation in dec_relb (standard deviation is 0.22 ), and much of the variation is across (and not within) proposed standards. The maximum average value of dec_relb is observed on the exposure draft for SFAS 141R, Business Combinations. A major provision in this exposure draft was to allow an acquirer to recognize acquired net assets at their fair values, without regard to the cost of the acquisition. Eliminating acquisition cost as the upper bound for net-asset-value recognition can introduce considerable subjectivity in financial reporting; thus it seems reasonable that SFAS 141R's exposure draft received a high dec_relb score.

\footnotetext{
${ }^{15}$ Two additional factors can confound predictions on political affiliation. First, the variables \% Dem Donor FASB and \% Rep Donor FASB are not collectively exhaustive because we cannot identify the political affiliation, if any, for FASB members in our sample who have never made campaign contributions in excess of $\$ 200$. Second, the political distance between Democrats and Republicans on the FASB is unlikely to be as wide as that in the general population, because FASB members are usually drawn from the relatively homogenous business community (including investors' representatives).
} 
The mean value of inc_relv (Manual_inc_relv) is $0.04(0.65)$. The median values of inc_relv and Manual_inc_relv are zero. The standard deviation of inc_relv is 0.17 (over four times the mean), suggesting, as with dec_relb, that there is considerable variance among comment letters in their assessments on increased "relevance." In unreported tests, we find that over two-thirds of this variation is across (and not within) proposed standards. The maximum average value of inc_relv for any given proposed SFAS is observed on the exposure draft for SFAS 159, The Fair Value Option for Financial Assets and Financial Liabilities. SFAS 159 is a standard intended to "improve relevance of financial statements" (FASB, 2007), so the high inc_relv score on the exposure draft is consistent with inc_relv measuring increased "relevance."

In untabulated tests, we further examine the validity of inc_relv and dec_relb as measures of increased "relevance" and decreased "reliability," respectively. Specifically, we randomly sampled 54 of the 908 big auditor comment letters (6\%) to manually assess whether the letters expressed sentiments on increased "relevance" and decreased "reliability." In all but five of the 54 sampled letters (9\%), our evaluation agreed with inc_relv and dec_relb. In all five exceptions, inc_relv and dec_relb were coded zero because the actual word stems "relevan" and "reliab" were never used, while our manual assessment was that the letters did in fact express sentiments on increased relevance and/or decreased reliability (i.e., there are no false positives in the coding of inc_relv and dec_relb). The 9\% misclassification refers exclusively to false negatives, which essentially result in a low power issue, biasing against finding results.

Table 2, Panel B, reports Pearson (Spearman above the diagonal) correlation coefficients between the dependent variables discussed above. The p-values on the correlation coefficients 
are based on clustering at the SFAS level. ${ }^{16}$ The variables dec_relb and Manual_dec_relb (inc_relv and Manual_inc_relv) are significantly correlated with each other, $\rho=0.341(\rho=0.203)$, at the $95 \%$ confidence level or higher, suggesting that our comment-letter-based proxies and our manually assessed proxies capture similar concepts. The various proxies for decreased "reliability" and increased "relevance" are also significantly correlated with each other. This result is consistent with the FASB's conception of "relevance" and "reliability" as trade-offs.

Table 3, Panel A, reports summary statistics for the FASB members' and SEC commissioners' personal characteristics. These measures constitute the set of explanatory variables in subsequent regression-based tests. The mean value of Tenure FASB is 4.2 and the median is 4.3 , suggesting that, on average, an exposure draft is issued by a board with just over four years of individual service experience. In contrast, the mean and median values of Tenure SEC are 3.1 and 3.0, respectively, suggesting SEC commissioners are on average less experienced in their extant jobs. Figure 1 plots the time series of Tenure FASB and Tenure SEC over the sample period. There does not appear to be any discernible time trend in average service experience on the two bodies.

On average, about $40 \%$ of FASB members were most recently employed in auditing (\% Auditor FASB), while about 4\% of FASB members were most recently employed in investment banking/ investment management (\% Financial FASB). Figure 2 plots the time series of these two variables over the 1973-2007 period: \% Auditor FASB appears to have held steady over time, while \% Financial FASB, which was zero through about the mid-1990s, appears to have increased to just under $30 \%$ in 2007 . The average proportion of SEC commissioners most recently employed in financial services (\% Financial SEC), at $15 \%$, is higher than the

\footnotetext{
${ }^{16}$ That is, significance of correlation coefficients is computed using the $t$ distribution as $\operatorname{Pr}\left(\frac{\rho * \sqrt{n-2}}{\sqrt{\left(1-\rho^{2}\right)}}>t(n-2)\right)$, where $\rho$ is the Pearson correlation coefficient and $n$ is the number of clusters (i.e., SFAS).
} 
corresponding FASB statistic. Figure 2 also plots the trend in \% Financial SEC, which appears to show considerable time series variation.

The average (median) proportion of FASB members contributing to the Democratic Party, \% Dem Donor FASB, is $16.73 \%$ (14\%). The statistics are similar for \% Rep Donor FASB at $18 \%(14 \%)$. Figure 3 plots the time series of these two variables: \% Dem Donor FASB is higher than \% Rep Donor FASB in the first few years of the FASB's existence, while \% Rep Donor FASB is higher in the period between 1995 and 2002. The average proportion of Democratic SEC commissioners (\% Democrat SEC) is 45\%, which indicates the average statistic for Republican SEC commissioners in about 55\%. Overall, the partisan proportions for SEC commissioners are higher than those for FASB members because the former are known with certainty and are collectively exhaustive in the sample. The time series variation in $\%$ Democrat SEC (Figure 4) is predictable, given that commissioners are appointed by the U.S. president. ${ }^{17}$

Pearson correlations (Spearman above the diagonal) between the explanatory variables in Panel A, Table 3 are shown in Panel B, Table 3. Statistical inferences are based on clustering by year. There are strong correlations between the background variables (i.e., tenure and prior employment) and the personal politics variables among FASB members and SEC commissioners. For example, Tenure FASB is positively associated with \% Rep Donor FASB (0.428) and negatively associated with \% Dem Donor FASB (-0.521); \% Auditor FASB is positively associated with both \% Rep Donor FASB (0.216) and \% Dem Donor FASB (0.519). Also, \% Financial SEC is negatively associated with \% Democrat SEC. These correlations are

\footnotetext{
${ }^{17}$ No more than three of the five SEC commissioners at any given time can belong to the same party; so, for example, a Democratic U.S. president cannot name five Democrats to the commission. Nevertheless, the proportion of SEC commissioners from the same party does sometimes exceed three-fifths because of vacancies and time lags between appointments.
} 
consistent with findings in prior research involving the backgrounds and personal politics of FCC commissioners (e.g., Gormley, 1979; Cohen, 1986).

\subsection{Multivariate research design}

We are interested in assessing how our measures of FASB proposals' impact on "reliability" and "relevance" vary with characteristics of standard setters. Accordingly, the dependent variables in our regressions are variously, dec_relb, inc_relv, Manual_dec_relb, and Manual_inc_relv. In specifying the explanatory variables in these regressions, we follow prior research on regulators by examining the effect of professional and political characteristics both independently and jointly. In the first set of regressions, we only include as explanatory variables the measures of FASB and SEC regulators' professional characteristics: Tenure FASB, \% Auditor FASB, \% Financial FASB, Tenure SEC, and \% Financial SEC. We do not include measures of the regulators' political characteristics because of the high observed correlations between political and personal characteristics. ${ }^{18}$ Appropriately, results from such regressions must be interpreted as exploratory, not definitive. The formal specification for our first set of regressions is given in equation (3).

$$
\begin{gathered}
\text { DepVar }_{i j}=f\left(\text { Tenure } A A S B_{j}, \% \text { Auditor } F A S B_{j}, \% \text { Financial } A S B_{j},\right. \\
\text { Tenure } \left.S E C_{j}, \% \text { Financial } S E C_{j}\right) \ldots(3)
\end{gathered}
$$

In equation (3), " $i$ ” is a big auditor comment letter and “ $j$ ” is an exposure draft. Standard errors in estimating equation (3) are clustered two-ways, by proposed SFAS and big auditor

\footnotetext{
${ }^{18}$ In his review of the literature on regulators' impact on regulation, Dal Bo (2006) notes that (p. 217) "although industry background seems to matter, it is not clear that it has a very strong effect once one considers the role of political affiliations." He attributes this result to the high correlations, noting, for example, that in the case of the FCC, "no Democratic administration appointed a commissioner with [broadcasting] industry background" during the 1955-1974 period. In essence, there is no ex-ante theory that suggests either professional or political characteristics are more important than the other in explaining regulatory decisions, and, given the given the high correlations and small sample sizes in these regressions, there is some value to examining professional and political characteristics independently.
} 
(using the method described in Petersen, 2009). We estimate two specifications of equation (3) (and all subsequent regressions), one with Big $\mathrm{N}$ auditor fixed effects and one without. The Big $\mathrm{N}$ auditor fixed effects specifically identify the "Big 5" auditors; thus for example, a comment letter by Touche Ross from the period preceding the establishment of Deloitte \& Touche will be identified by a Deloitte \& Touche fixed effect.

We test for the association between our dependent variables and the FASB and SEC regulators' political characteristics (i.e., \% Dem Donor FASB, \% Rep Donor FASB, \% Democrat $S E C)$ in a second set of regressions. The formal specification for our second set of regressions is given in equation (4) below.

$$
\text { DepVar }_{i j}=f\left(\% \text { Rep Donor FASB }, \% \text { Dem Donor FASB }, \% \text { Democrat } S E C_{j}\right) \ldots(4)
$$

In equation (4), DepVar and the subscripts " $i$ " and " $j$ " are as defined in equation (3). Standard error clusters are also as described earlier.

In a final set of regressions, we include all independent variables described in equations (3) and (4). Coefficients in all regressions are estimated using ordinary least squares (OLS). We report results both with and without controls for two market-based variables: the annual valueweighted market return (VWRETD) and the standard deviation of the daily value-weighted market return (sd_VWRETD) in the twelve months preceding the issuance of a proposed SFAS.

\section{Multivariate results}

\subsection{Results using Big $N$ auditors’ comment letters}

Table 4 reports OLS estimation results where the measure of decreased "reliability" from auditor comment letters (dec_relb) is the dependent variable. There are seven columns to Table

4. In the first three columns, FASB members' and SEC commissioners' professional 
characteristics are the explanatory variables (as in equation (3)); in columns four to six, FASB members' and SEC commissioners' political affiliations are the explanatory variables (as in equation (4)); the seventh column reports the regression combining all explanatory variables. In the first and fourth columns, we do not include the market-based variables, VWRETD and sd_VWRETD, as temporal economic controls; in all other columns, these variables are included. In addition, columns two and five do not include auditor fixed effects, whereas columns three, six, and seven do. In the following discussion, we focus on the results from columns three, six, and seven, since these columns have the most exhaustive specifications, only discussing the other columns when inferences differ. All regressions in Table 4 use the sample of 908 comment letters. Standard errors in all regressions are clustered by Big N auditor and SFAS, and are robust to heteroskedasticity.

When professional characteristics are examined independently, we find both Tenure FASB and Tenure SEC are positively associated with decreased "reliability," suggesting that longer terms of service on the FASB and SEC are associated with a perception of decreased accounting "reliability" (the coefficient on Tenure FASB is insignificant when market-based controls are excluded). If decreased "reliability" is an undesirable accounting property, this result is consistent with longer term-lengths compromising regulatory outcomes, per Stigler's theory of regulation. To put the coefficients' magnitudes in perspective, the implication from column (3) is that a one standard deviation increase in FASB tenure (SEC tenure) is associated with a decrease in "reliability" that is about $30 \%(38 \%)$ of the mean dec_relb value. We also find evidence that $\%$ Financial FASB and \% Financial SEC are positive and significant predictors of FASB proposals perceived as decreasing accounting "reliability." A one standard deviation increase in \% Financial FASB (\% Financial SEC) is associated with a decrease in "reliability" that is about 
$74 \%$ (49\%) of the mean dec_relb value. This evidence is consistent with the proposition that a prior career in investment banking/ investment management predisposes standard setters to produce standards that deemphasize accounting "reliability." Contrary to our expectations, we find no evidence in Table 4 linking \% Auditor FASB and decreased "reliability."

When political characteristics are examined independently, the coefficient on $\%$ Dem Donor FASB is significant and negative in explaining dec_relb. The implication from column (6) is that a one standard deviation increase in \% Dem Donor FASB is associated with an increase in "reliability" that is about $64 \%$ of the mean dec_relb value. The evidence suggests that increased proportional representation of Democrats on the FASB is associated with the production of standards that are viewed as increasing accounting "reliability." We do not find a similar result with the proportion of Democrats on the SEC.

In combining all explanatory variables in column (7), only the results on \% Financial FASB and \% Financial SEC are statistically significant. This result is consistent with prior studies that combine regulators' professional and political characteristics, where high correlations between these variables and the small population size are seen to confound statistical inferences (Dal Bo, 2006). However, in unreported tests we find variance inflation factors from this regression are inconsistent with severe multicollinearity suggesting that, for our sample, financial services affiliation is the overriding explanatory variable.

Table 5 reports OLS estimation results where the measure of increased "relevance" from auditor comment letters (inc_relv) is the dependent variable. Table 5 is otherwise identical to Table 4 in all respects. As in Table 4, we focus on discussing results from columns three, six, and seven of Table 5. When professional characteristics alone are the explanatory variables, we find only \% Financial FASB is a positive and significant predictor of FASB proposals perceived as 
increasing accounting "relevance." In column (3), one standard deviation increase in \% Financial FASB is associated with an increase in "relevance" that is about $73 \%$ of its mean value. This evidence is consistent with the proposition that a prior career in investment banking/ investment management predisposes standard setters to produce standards that increase accounting "relevance." When political characteristics alone are the explanatory variables, we find \% Dem Donor FASB is significant and negative in explaining inc_relv. In column (6), one standard deviation increase in \% Dem Donor FASB is associated with a decrease in "relevance" that is about $65 \%$ of the mean inc_relv value. Column (6) also reveals a statistically negative association between \% Rep Donor FASB and proposals perceived as increasing "relevance." We are not aware of a theory to interpret this result. In combining all explanatory variables in column (7) of Table 5, only the coefficient on \% Financial FASB is statistically significant.

To summarize the key findings from Tables 4 and 5: across tests using auditor comment letters, the data are consistent with the proposition that a prior career in financial services predisposes FASB standard setters to favor accounting "relevance" over "reliability."

\subsection{Results using manual assessments of exposure drafts}

Our primary comment-letter-based measures of decreased "reliability" and increased "relevance" are sensitive to auditors' distinct incentives, which may be endogenous to our explanatory variables. Accordingly, we use manual assessments by two research assistants, as discussed in Section 3 and Appendix B, as alternative dependent variables (Manual_dec_relb and Manual_inc_relv) to address this concern.

Table 6 Panel A presents the descriptive statistics for: (A) the exposure drafts common to both our manual and comment-letter sample ( $\mathrm{n}=126)$; (B) the sub-sample of exposure drafts for 
which we only have manual assessments $(\mathrm{n}=19)$; and $(\mathrm{C})$ the sub-sample of exposure drafts for which we only have auditor comment letters $(n=23)$. Using a two-sample differences-in-means $t-$ test we compare the average values of explanatory variables across the three groups. Of particular note, Tenure FASB and Tenure SEC are significantly lower in sub-sample (C), while \% Dem Donor FASB is significantly higher. These differences are largely caused by data availability for the manually assessed sub-sample. That sub-sample (columns (A) and (B)) excludes several exposure drafts from the early years of the FASB (1980s and before), a period characterized by lower values for Tenure FASB and Tenure SEC and higher values for \% Dem Donor FASB, as shown in Figures 1-3.

Table 6 Panel B presents OLS estimation results where Manual_dec_relb and Manual_inc_relv are the dependent variables. There are six columns to Table 6 Panel B: Manual_dec_relb is the dependent variable for the first three columns, Manual_inc_relv for the next three. The first column for each dependent variable includes only regulators' professional characteristics as independent variables; the second column for each dependent variable includes only regulators' political characteristics as independent variables; the final column for each dependent variable includes both professional and political characteristics. In all columns, we include auditor fixed effects and the market-based controls. Each regression is based on 126 observations, one for each exposure draft where both auditor comment letters and manual assessments are available. Standard errors are heteroskedasticity robust.

The results in Table 6 Panel B show that \% Financial FASB is a significant determinant of both Manual_dec_relb and Manual_inc_relv, which is consistent with regression results using auditor comment letters (Tables 4 and 5). As in Table 4, we find a significant negative coefficient on \% Dem Donor FASB in regressions on Manual_dec_relb that include only 
political variables; we do not find a similar result on Manual_inc_relv. In contrast to Table 4, in Table 6 Panel B we do not find significant coefficients on Tenure FASB, Tenure SEC, and \% Financial SEC in regressions on Manual_dec_relb. The non-results on the tenure variables are likely explained by the exclusion of several exposure drafts in the Table 6 Panel B regressions due to data limitations, as discussed above.

Overall, to summarize the key findings from Tables 4, 5, and 6: across tests using auditor comment letters and manual assessments of exposure drafts, the data are consistent with the proposition that a prior career in financial services predisposes FASB standard setters to favor accounting "relevance" over "reliability." Our coding rubric for the manual assessment of exposure drafts" focus on "relevance" over "reliability" relies on the use of fair-value methods in these proposals (see Appendix B for details). Thus, the key finding on financial services affiliation can be explained, in part, as the tendency of regulators with a financial services background to propose standards that use fair-value methods in recognition and disclosure. When combined with the descriptive evidence from Figure 2 and Table 3, which shows an increase in the proportion of FASB members from financial services from the mid-1990s through 2007, this result can provide a partial explanation for the growth of fair-value accounting.

\subsection{Robustness and sensitivity tests}

With the small population of FASB and SEC regulators in our sample, there is a concern that one individual with an extremely strong personality can be driving the results described thus far. The analogous literature on managers and firm policies employs technologies around jobswitching to address this concern (e.g., Bertrand and Schoar, 2003). Due to the unique nature of the task we study, i.e., standard setting not corporate management, we cannot employ these 
technologies. An alternative robustness test is a jackknifing procedure where we re-estimate all our regressions successively eliminating each regulator (and reconstructing all independent variables accordingly) to determine if any member was instrumental to our statistical inferences. Unreported results obtained from this procedure are inconsistent with the proposition that any one FASB member is instrumental to the factors previously identified as statistically significant: Across 39 jackknifed subsamples — each eliminating one FASB member-we find no cases where elimination of an individual from our sample changes the sign or significance of our primary results. ${ }^{19}$

The implicit assumption underlying construction of our independent variables is that an exposure draft represents the average position of all extant FASB members and SEC commissioners; however, it is possible that the chairmen of these groups have greater influence than other members. In unreported robustness tests, we examine the effects of assigning greater weight to FASB and SEC chairmen when calculating the average background characteristics of an extant board. In particular, we assign the background characteristics of FASB and SEC chairmen twice the weight of non-chair members. While the choice of doubling the weight on chairmen is admittedly arbitrary, the objective of this test is simply to assess whether the relative importance of FASB chairmen subsumes the results shown earlier. All substantive results discussed in Tables 4 and 5 are robust to the procedure described above.

Finally, as discussed earlier, it is possible that the selection of a set of regulators on the FASB and SEC in a given time period depends, at least in part, on more fundamental macroeconomic conditions. Accordingly, we study the sensitivity of our results to these

\footnotetext{
${ }^{19}$ The successive elimination of two FASB members in the jackknife procedure does turn, in some cases, the previously insignificant coefficient on \%Auditor FASB significantly negative (as predicted): one of these members has a financial services background, the other an auditing background. One implication is that our failure to find evidence on \%Auditor FASB in the regression that includes all independent variables is driven by the influential effects of these members.
} 
conditions. In restricting the sample to periods of expansion in the U.S. economy (as identified by the NBER), financial services background and Democratic Party affiliations remain significant predictors of increased "relevance" (inc_relv) and decreased "reliability" (dec_relb), consistent with results reported in Tables 4 and 5. The only result from those tables not carrying through is the negative coefficient on \% Rep Donor FASB on inc_relv for which we have no exante prediction and which is not consistent across all specifications.

\section{Conclusions}

Motivated by an interest in broadening the understanding of accounting standard setting beyond the role of constituent comment-letter lobbying and congressional intervention, we examine the role of FASB and SEC regulators in the process. Specifically, we examine how the professional and political characteristics of these regulators vary in the nature of exposure drafts proposed from 1973 to 2007 . Because there is no obvious metric to evaluate the proposals, we rely principally on Big $\mathrm{N}$ auditors' contemporaneous evaluations of the exposure drafts along dimensions of "reliability" and "relevance." Our focus on "reliability" and "relevance" reflects our judgment on their importance to accounting, also evidenced in several leading accounting textbooks and in the FASB's conceptual framework. The regulators' professional characteristics we study are tenure, background in auditing, and background in financial services; the political characteristics are affiliation, if any, with the Democratic and Republican parties. Our key finding is that FASB members with a prior professional affiliation with the financial services industry are more likely to propose standards that decrease "reliability" and increase "relevance," partly due to their tendency to propose fair-value methods of measurement. Given that the proportion of FASB members from the financial services industry has increased from the mid- 
1990s to 2007, this finding can provide a partial explanation for the growth of fair-value accounting. We also find that FASB members affiliated with the Democratic Party are more likely to propose standards that increase "reliability" and decrease "relevance," although only when excluding financial-services affiliation as an independent variable. Since our statistical inferences are based on a small population of FASB and SEC regulators, we conduct jackknifed sensitivity analyses: we find no evidence that any one regulator is driving inferences.

Broadly, the paper provides a first empirical look at an important feature in the political economy of U.S. GAAP: the role of regulators at the FASB and SEC. While our research design does not allow us to distinguish whether the documented role of regulators derives from some intrinsic ideology of these individuals or from more primitive selection effects that place these regulators in office, our study takes the first important step of examining the impact of individual standard setters on standard setting (in the spirit of Bertrand and Schoar's analogous study of managers on firm policies). Our study highlights opportunities for work on the question of how accounting regulators are chosen, including issues such as whether there is a "revolving door" between standard setters and special-interest groups. Moreover, as accounting institutions worldwide reorganize in response to globalization, such research can have important practical implications in the area of regulatory design. ${ }^{20}$

\footnotetext{
${ }^{20}$ For example, in the past five years, both Canada and China have undertaken some revamping of their standardsetting institutions (e.g., Ramanna and Cheng, 2009; Ramanna, Donovan, and Dai, 2010). Further, in the U.S., between 2008 and 2010, the FASB has pared down and increased its membership from seven to five and back to seven, in order to "protect and maintain its efficiency" (FAF, 2008, 2010). Given the paucity of evidence to guide such structural changes, most, if not all of the institutional transformations have been ad hoc.
} 


\section{References}

Bamber, L., Jiang, J., Wang, I., 2010. What's my style? The influence of top managers on voluntary corporate financial disclosure. The Accounting Review 85, 1131-1162.

Barth, M., 2006. Research, standard setting, and global financial reporting, Foundation and Trends in Accounting 1, 71-165.

Bertomeu, J., Magee, R., 2011. From low-quality reporting to financial crises: Politics of disclosure regulation along the economic cycle. Journal of Accounting and Economics 52, 209-227.

Bertrand, M., Schoar, A., 2003. Managing with style: The effect of managers on firm policies. Quarterly Journal of Economics 118, 1169-1208.

Cohen, J., 1986. The dynamics of the "revolving door" on the FCC. American Journal of Political Science 30, 689-708.

Dal Bo, E., 2006. Regulatory capture: a review. Oxford Review of Economic Policy 22, 203225.

Dyckman, T., Magee, R., Pfeiffer, G., 2011. Financial Accounting (3e). Cambridge Business Publishers, Westmont, IL.

Dyreng, S., Hanlon, M., Maydew, E., 2010. The effects of executives on corporate tax avoidance. The Accounting Review 85, 1163-1189.

Financial Accounting Foundation (FAF), 2008. The Financial Accounting Foundation board of trustees approves changes to oversight, structure and operations of FAF, FASB and GASB. FAF News Release February 26, Norwalk, CT.

Financial Accounting Foundation (FAF), 2010. Financial Accounting Foundation to increase size of FASB. FAF News Release August 24, Norwalk, CT.

Financial Accounting Standards Board (FASB), 1978. Statement of Financial Accounting Concepts No. 1, Objectives of financial reporting by business enterprises. FASB, Norwalk, CT.

Financial Accounting Standards Board (FASB), 1980. Statement of Financial Accounting Concepts No. 2, Qualitative characteristics of accounting information. FASB, Norwalk, CT.

Financial Accounting Standards Board (FASB), 2007. FASB standard establishes fair value option for financial assets and liabilities. FASB News Release February 15, Norwalk, CT.

Ge, W., Matsumoto, D., Zhang, J., 2010. Do CFOs have style? An empirical investigation of the effect of individual CFOs on accounting practices. Contemporary Accounting Research 28, 1141-1179. 
Gormley, W., 1979. A test of the revolving door hypothesis at the FCC. American Journal of Political Science 23, 665-683.

Healy, P., Whalen, J., 1999. A review of the earnings management literature and its implications for standard setting. Accounting Horizons 13, 365-383.

Investment Company Institute (ICI), 2008. Comment letter by CEO Paul S. Stevens on the SEC's request for comment on mark-to-market accounting. Available at: http://www.ici.org/pdf/23068.pdf (accessed, April, 2011).

Johnson, L., 2005. Relevance and reliability: The FASB report. Available at: www.fasb.org.

Kalt, J., Zupan, M., 1984. Capture and ideology in the economic theory of politics. American Economic Review 74, 279-300.

Kau, J., Rubin, P., 1979. Self-interest, ideology, and logrolling in congressional voting. Journal of Law and Economics 22, 365-384.

Kellogg, R., 1984. Accounting activities, security prices, and class action lawsuits. Journal of Accounting \& Economics 6, 185-204.

Kothari, S., Ramanna, K., Skinner, D., 2010. Implications for GAAP from an analysis of positive research in accounting. Journal of Accounting \& Economics 50, 246-286.

Kothari, S., Shu, S., Wysocki, P., 2009. Do managers withhold bad news? Journal of Accounting Research 47, 241-276.

LaFond, R., Watts, R., 2008. The information role of conservative financial statements. The Accounting Review 83, 447-478.

Leaver, C., 2009. Bureaucratic minimal squawk behavior: Theory and evidence from regulatory agencies. American Economic Review 99, 572-607.

Nelson, M., Elliott, J., Tarpley, R., 2002. Evidence from auditors about managers' and auditors' earnings management decisions. The Accounting Review 77, 175-202.

Petersen, M., 2009. Estimating standard errors in finance panel data sets: Comparing approaches. Review of Financial Studies 22, 435-480.

Ramanna, K., 2006. The implications of unverifiable fair-value accounting: Evidence from the political economy of goodwill accounting. Presentation at the Journal of Accounting \& Economics Conference, Northwestern University.

Ramanna, K., 2008. The implications of unverifiable fair-value accounting: Evidence from the political economy of goodwill accounting. Journal of Accounting \& Economics 45, 253-281.

Ramanna, K., Cheng, B., 2009. Choosing a GAAP for Canada. Harvard Business School Case $110-023$. 
Ramanna, K., Donovan, G., Dai, N., 2010. IFRS in China. Harvard Business School Case 110037.

Stickney, C., Weil, R., Schipper, K., Francis, J., 2010. Financial Accounting (13e). SouthWestern Cengage Learning, Mason, $\mathrm{OH}$.

Schipper, K., 2005. Fair values in financial reporting. Presentation at American Accounting Association Annual Meetings, August 2005. Available at: http://fars.org/2005AAAFairValueKSchipper.pdf (last accessed September 15, 2009).

Stigler, G., 1971. The theory of economic regulation. Bell Journal of Economics 2, 3-21.

Watts, R., 2003. Conservatism in accounting Part I: explanations and implications. Accounting Horizons 17, 207-221.

Watts, R., Zimmerman, J., 1978. Towards a positive theory of the determination of accounting standards. The Accounting Review 53, 112-134.

Watts, R., Zimmerman, J., 1982. Auditors and the determination of accounting standards. Working paper, University of Rochester.

Watts, R., Zimmerman, J., 1983. Auditor independence and scope of services. Working paper, University of Rochester.

Zhang, J., 2008. The contracting benefits of accounting conservatism to lenders and borrowers. Journal of Accounting \& Economics 45, 27-54. 


\section{Appendix A \\ Details of the process for creating auditor-based measures of decreased "reliability" and increased "relevance"}

We use a custom-designed Perl script to analyze the Big $\mathrm{N}$ auditors' comments letters. For each comment letter, the Perl program first identifies all instances of the word stems "relevan" and "reliab." The program then outputs: (1) the exact position within the comment letter where a word stem of interest occurs (the position of a word stem is reported as its word count from the beginning of the document); (2) the entire sentence containing the identified word stem; and (3) the total word count for the letter.

Next, a research assistant (RA) trained in accounting principles, but blind to the intent of our study, manually examines both the first sentence referencing "relevan" and the first sentence referencing "reliab." On each sentence, the RA determines whether the word stem in question is being used in: (1) a positive context, i.e., whether the letter is indicating that the proposed standard will increase "relevance"/ "reliability;" (2) a negative context, i.e., whether the letter is indicating that the proposed standard will decrease "relevance"/ "reliability;" or (3) a context that is irrelevant to the use of "relevance" and "reliability" as accounting principles. Examples of the RA's assessments from actual sentences in the comment letters are below.

- Positive context: "We support the approach followed in the Exposure Draft and believe that application of those standards will provide relevant and understandable information as well as an appropriate balance between comparability and flexibility." Source: Arthur Andersen's comment letter on proposed SFAS 117.

- Negative context: "We also believe the Proposed Standard exacerbates the complexities of Statement 125 and permits recognition of revenue that cannot be reliably measured." Source: Deloitte's comment letter on proposed SFAS 140.

- Irrelevant usage: "The auditor should familiarize himself with the relevant provisions of the partnership agreement." Source: Arthur Andersen's comment letter on proposed SFAS 102.

In instances where the research assistant identifies the comment letter's first use of "relevance"/ "reliability" as irrelevant to accounting principles, the RA proceeds to the second sentence containing the word stem in question. This process continues until the RA encounters either a positive or negative use of "relevance"/ "reliability" or the RA determines that all uses of "relevance"/ "reliability" in the comment letter are irrelevant to accounting principles. 


\section{Appendix B \\ Coding rubric for research-assistant-based measures of decreased "reliability" and increased "relevance"}

The research assistants were instructed to evaluate the exposure drafts recording their perspective on whether the underlying proposal would decrease "reliability," where "reliability" is defined as per the FASB as, "The quality of information that assures that information is reasonably free from error and bias and faithfully represents what it purports to represent." The resulting variable is a binary indicator denoted Manual_dec_relb. To obtain research assistants' assessments of exposure drafts' increased "relevance," we rely on the following procedure: we asked the research assistants to score each exposure draft on the nature of its use of fair-value accounting. Our focus on "fair values" in measuring "increased relevance" is motivated by the FASB viewing the former as resulting in the latter (e.g., Johnson, 2005). In particular, research assistants scored each exposure draft on a score of $0-5$, with unit scores for each of the following: (1) the introduction of fair-value accounting for asset write-downs; (2) the introduction of fair-value accounting for asset recognition and remeasurement; (3) the introduction of fair-value accounting for liability recognition and remeasurement; (4) the recognition of fair-value changes in the income statement; and (5) the required disclosure of fairvalue amounts. The resulting count variable is denoted, Manual_inc_relv.

Assessing Manual_dec_relb and the components of Manual_inc_relv requires the exercise of professional judgment. Accordingly, both research assistants employed for this task are seasoned professionals, with MBA degrees from top-ranked U.S. business schools (as per U.S. News rankings) and with combined industrial work experience in finance and accounting exceeding thirty years. We recruited both research assistants specifically to evaluate the FASB exposure drafts, and both were selected for their practical familiarity with accounting.

Of the 145 exposure drafts coded by the two research assistants, 105 received identical evaluations on Manual_dec_relb, while 114 received identical evaluations on Manual_inc_relv. On the exposure drafts with differing evaluations, the research assistants were able to resolve all differences in subsequent discussions. At no point in this process were the research assistants apprised of the study's hypotheses or its independent variables. Research assistants were compensated on a flat hourly wage (i.e., no performance-based pay). 


\section{Appendix C \\ Variable definitions}

\begin{tabular}{|c|c|}
\hline VARIABLE & DESCRIPTION \\
\hline \multicolumn{2}{|l|}{ Dependent Variables } \\
\hline inc_relv & $\begin{array}{l}\text { Assessment that a proposed SFAS will increase accounting } \\
\text { "relevance" as expressed by the Big } 8 / 6 / 5 / 4 \text { auditors (hereafter } \\
\text { "Big N auditors") in their comment letters. See Section } 3 \text {. }\end{array}$ \\
\hline dec_relb & $\begin{array}{l}\text { Assessment that a proposed SFAS will decrease accounting } \\
\text { "reliability" as expressed by the Big N auditors in their comment } \\
\text { letters. See Section } 3 \text {. }\end{array}$ \\
\hline Manual_inc_relv & $\begin{array}{l}\text { Assessment that a proposed SFAS will increase "relevance" as } \\
\text { determined by } 2 \text { independent reviewers. See Section } 3 \text {. }\end{array}$ \\
\hline Manual_dec_relb & $\begin{array}{l}\text { Assessment that a proposed SFAS will decrease "reliability" as } \\
\text { determined by } 2 \text { independent reviewers. See Section } 3 .\end{array}$ \\
\hline \multicolumn{2}{|c|}{ FASB \& SEC Professional Characteristics } \\
\hline Tenure FASB & $\begin{array}{l}\text { Exposure draft (ED)-level measure of the average tenure in years } \\
\text { of all extant FASB members }\end{array}$ \\
\hline \% Auditor FASB & $\begin{array}{l}\text { ED-level measure of the proportion of extant FASB members with } \\
\text { most recent former employ in auditing. }\end{array}$ \\
\hline \% Financial FASB & $\begin{array}{l}\text { ED-level measure of the proportion of extant FASB members with } \\
\text { most recent former employ in investment banking/investment } \\
\text { management }\end{array}$ \\
\hline Tenure SEC & $\begin{array}{l}\text { ED-level measure of the average tenure in years of all extant SEC } \\
\text { commissioners }\end{array}$ \\
\hline \% Financial SEC & $\begin{array}{l}\text { ED-level measure of the proportion of extant SEC commissioners } \\
\text { with most recent former employ in financial services }\end{array}$ \\
\hline \multicolumn{2}{|c|}{ FASB \& SEC Political Characteristics } \\
\hline \%Rep Donor FASB & $\begin{array}{l}\text { ED-level measure of the proportion of extant FASB members } \\
\text { making campaign contributions to the Republican party or } \\
\text { candidates. }\end{array}$ \\
\hline$\%$ Dem Donor FASB & $\begin{array}{l}\text { ED-level measure of the proportion of extant FASB members } \\
\text { making campaign contributions to the Democratic party or } \\
\text { candidates }\end{array}$ \\
\hline \% Democrat SEC & $\begin{array}{l}\text { ED-level measure of the proportion of extant Democratic SEC } \\
\text { commissioners. }\end{array}$ \\
\hline \multicolumn{2}{|l|}{ Other Variables } \\
\hline VWRETD & $\begin{array}{l}\text { Annual value-weighted market return (from CRSP) for the } 12 \\
\text { months directly preceding the month in which ED was issued. }\end{array}$ \\
\hline sd_VWRETD & $\begin{array}{l}\text { Standard deviation of daily VWRETD (CRSP) for the } 12 \text { months } \\
\text { directly proceeding the month in which an ED was issued }\end{array}$ \\
\hline
\end{tabular}




\section{Appendix D \\ Dependent variable scores by exposure draft}

\begin{tabular}{|c|c|c|c|c|c|c|}
\hline SFAS & ED Title & ED Date & dec_relb & inc_relv & $\begin{array}{c}\text { Manual__ } \\
\text { dec_relb }\end{array}$ & $\begin{array}{r}\text { Manual_ } \\
\text { inc_relv }\end{array}$ \\
\hline SFAS001 & Disclosure of Foreign Currency Translation Information & $10 / 19 / 73$ & 0.000 & 0.000 & NA & NA \\
\hline SFAS002 & Accounting for Research and Development Costs & $06 / 05 / 74$ & 0.000 & 0.000 & NA & NA \\
\hline SFAS003 & Reporting Accounting Changes in Interim Financial Statements: an amendment of APB Opinion No. 28 & $11 / 11 / 74$ & 0.000 & 0.000 & 0.000 & 0.000 \\
\hline SFAS004 & Reporting Gains and Losses and Extinguishments of Debt: an amendment of APB Opinion No. 30 & $01 / 31 / 75$ & 0.000 & 0.000 & NA & NA \\
\hline SFAS005 & Accounting for Contingencies & $10 / 21 / 74$ & 0.000 & 0.000 & NA & NA \\
\hline SFAS006 & $\begin{array}{l}\text { Classification of Short-term Obligations Expected to Be Refinanced: an amendment of ARB No. 43, } \\
\text { Chapter 3, Section A }\end{array}$ & $11 / 11 / 74$ & 0.000 & 0.000 & NA & NA \\
\hline SFAS007 & $\begin{array}{l}\text { Accounting and Reporting by Development Stage Companies, Subsidiaries, Divisions and Other } \\
\text { Components }\end{array}$ & $07 / 19 / 74$ & 0.000 & 0.000 & NA & NA \\
\hline SFAS008 & $\begin{array}{l}\text { Accounting for the Translation of Foreign Currency Transactions and Foreign Currency Financial } \\
\text { Statements }\end{array}$ & $12 / 31 / 74$ & 0.000 & 0.000 & NA & NA \\
\hline SFAS009 & $\begin{array}{l}\text { Accounting for Income Taxes--Oil and Gas Producing Companies: an amendment of APB Opinions No. } \\
11 \text { and } 23\end{array}$ & $04 / 25 / 75$ & 0.000 & 0.000 & NA & NA \\
\hline SFAS010 & $\begin{array}{l}\text { Extension of "Grandfather" Provisions for Business Combinations: An Amendment of APB Opinion No. } \\
16\end{array}$ & $09 / 08 / 75$ & 0.000 & 0.000 & NA & NA \\
\hline SFAS011 & Accounting for Contingencies--Transition Method: An Amendment of FASB Statement No.5 & $10 / 31 / 75$ & 0.000 & 0.000 & NA & NA \\
\hline SFAS012 & Accounting for Certain M arketable Securities & $11 / 06 / 75$ & 0.000 & 0.000 & NA & NA \\
\hline SFAS013 & Accounting for Leases & $08 / 26 / 75$ & 0.000 & 0.000 & NA & NA \\
\hline SFAS013 & Accounting for Leases: Revision of Exp osure Draft Issued August 26, 1975 & $07 / 22 / 76$ & 0.000 & 0.000 & $\mathrm{NA}$ & NA \\
\hline SFAS014 & Financial Reporting for Segments of a Business Enterprise & $09 / 30 / 75$ & 0.094 & 0.000 & NA & NA \\
\hline SFAS015 & Restructuring of Debt in a Troubled Loan Situation & $11 / 07 / 75$ & 0.000 & 0.000 & NA & $\mathrm{NA}$ \\
\hline SFAS015 & Accounting by Debtors and Creditors for Troubled Debt Restructurings & $12 / 30 / 76$ & $\mathrm{NA}$ & $\mathrm{NA}$ & 1.000 & 0.000 \\
\hline SFAS016 & Prior Period Adjustments & $07 / 29 / 76$ & 0.000 & 0.000 & $\mathrm{NA}$ & NA \\
\hline SFAS017 & Accounting for Leases--Initial Direct Costs: An Amendment of FASB Statement No. 13 & $08 / 08 / 77$ & 0.000 & 0.000 & 0.000 & 0.000 \\
\hline SFAS018 & $\begin{array}{l}\text { Financial Reporting for Segments of a Business Enterprise--Interim Financial Statements: An Amendment } \\
\text { of FASB Statement No. } 14\end{array}$ & $09 / 20 / 77$ & 0.000 & 0.000 & 0.000 & 0.000 \\
\hline SFAS019 & Financial Accounting and Reporting by Oil and Gas Producing Companies & $07 / 15 / 77$ & 0.000 & 0.000 & 0.000 & 0.000 \\
\hline SFAS020 & Accounting for Forward Exchange Contracts / an amendment of FASB Statement No. 8 & $11 / 07 / 77$ & 0.000 & 0.000 & 0.000 & 0.000 \\
\hline SFAS021 & $\begin{array}{l}\text { Suspension of the Reporting of Earnings per Share and Segment Information by Nonpublic Enterprises: an } \\
\text { amendment of APB Opinion No. } 15\end{array}$ & $02 / 27 / 78$ & 0.000 & 0.000 & 0.000 & 0.000 \\
\hline $\begin{array}{l}\text { SFAS022 } \\
\text { /SFAS023 }\end{array}$ & $\begin{array}{l}\text { Accounting for Leases: I Inception of the Lease: An Amendment of FASB Statement No. } 13 \text { II Changes in } \\
\text { the Provisions of Lease Agreements Resulting from Refundings of Tax-Exempt Debt: an amendment of } \\
\text { FASB Statement No. } 13\end{array}$ & $12 / 19 / 77$ & 0.000 & 0.000 & 0.000 & 0.000 \\
\hline SFAS024 & $\begin{array}{l}\text { Reporting Segment Information in Financial Statements That Are Presented With Another Enterprise's } \\
\text { Financial Report: an amendment of FASB Statement No. } 14\end{array}$ & $07 / 19 / 78$ & 0.000 & 0.000 & 0.000 & 0.000 \\
\hline SFAS025 & $\begin{array}{l}\text { Suspension of Certain Accounting Requirements for Oil and Gas Producing Companies: an amendment of } \\
\text { FASB Statement No. } 19\end{array}$ & $11 / 07 / 78$ & 0.000 & 0.000 & 0.000 & 0.000 \\
\hline SFAS026 & Profit Recognition on Sales-Type Leases of Real Estate: an amendment of FASB Statement No. 13 & $12 / 22 / 78$ & 0.000 & 0.000 & 0.000 & 0.000 \\
\hline SFAS027 & $\begin{array}{l}\text { Classification of Renewals or Extensions of Existing Sales-Type or Direct Financing Leases: an amendment } \\
\text { of FASB Statement No. } 13\end{array}$ & $02 / 13 / 79$ & 0.000 & 0.000 & 0.000 & 0.000 \\
\hline SFAS028 & Accounting for Sales with Leasebacks: an amendment of FASB Statement No. 13 & $12 / 21 / 78$ & 0.000 & 0.000 & 1.000 & 0.000 \\
\hline SFAS029 & Determining Contingent Rentals & $12 / 21 / 78$ & 0.000 & 0.000 & 0.000 & 0.000 \\
\hline SFAS030 & Disclosure of Information about Major Customers: an amendment of FASB Statement No. 14 & $03 / 29 / 79$ & 0.000 & 0.000 & 0.000 & 0.000 \\
\hline SFAS031 & Accounting for Income Taxes Related to U.K. Tax Legislation Concerning Stock Relief & $07 / 30 / 79$ & 0.000 & 0.000 & 1.000 & 0.000 \\
\hline SFAS032 & $\begin{array}{l}\text { Specialized Accounting and Reporting Principles and Practices in AICPA Industry Accounting Guides, } \\
\text { Industry Audit Guides, and Statements of Position: an amendment of APB Opinion No. } 20\end{array}$ & $06 / 01 / 79$ & 0.000 & 0.000 & 0.000 & 0.000 \\
\hline SFAS033 & Financial Reporting in Units of General Purchasing Power & $12 / 31 / 74$ & $\mathrm{NA}$ & NA & $\mathrm{NA}$ & NA \\
\hline SFAS033 & Financial Reporting and Changing Prices & $12 / 28 / 78$ & NA & NA & 0.000 & 0.000 \\
\hline SFAS033 & $\begin{array}{l}\text { Constant Dollar Accounting: supp lement to an exposure draft of a proposed Statement of Financial } \\
\text { Accounting Standards, Financial Reporting in Units of General Purchasing Power }\end{array}$ & $03 / 02 / 79$ & 0.086 & 0.000 & 0.000 & 0.000 \\
\hline SFAS034 & Capitalization of Interest Cost & $12 / 15 / 78$ & 0.000 & 0.000 & 0.000 & 0.000 \\
\hline SFAS035 & Accounting and Reporting by Defined Benefit Pension Plans & $04 / 14 / 77$ & 0.000 & 0.116 & 1.000 & 4.000 \\
\hline SFAS035 & $\begin{array}{l}\text { Accounting and Reporting by Defined Benefit Pension Plans: revision of exposure draft issued April 14, } \\
1977\end{array}$ & $07 / 09 / 79$ & NA & NA & 1.000 & 3.000 \\
\hline SFAS036 & $\begin{array}{l}\text { Disclosure of Pension and Other Post-Retirement Benefit Information: an amendment of APB Opinion } \\
\text { No. } 8\end{array}$ & $07 / 12 / 79$ & 0.000 & 0.000 & 0.000 & 0.000 \\
\hline SFAS037 & Balance Sheet Classification of Deferred Income Taxes: an amendment of APB Opinion No. 11 & $03 / 14 / 80$ & 0.000 & 0.000 & 0.000 & 0.000 \\
\hline SFAS038 & $\begin{array}{l}\text { Accounting for Preacquisition Contingencies of Purchased Enterprises: an amendment of APB Opinion } \\
\text { No. } 16\end{array}$ & $12 / 26 / 79$ & 0.000 & 0.000 & 1.000 & 0.000 \\
\hline $\begin{array}{l}\text { SFAS039 } \\
\text { /SFAS040/S } \\
\text { FAS041 }\end{array}$ & Financial Reporting and Changing Prices: Specialized Assets - a supplement to FASB Statement No. 33 & $04 / 21 / 80$ & 0.448 & 0.130 & 0.000 & 1.000 \\
\hline
\end{tabular}




\section{Appendix D ...Cont.}

\begin{tabular}{|c|c|c|c|c|c|c|}
\hline SFAS & ED Title & ED Date & dec_relb & inc_relv & $\begin{array}{c}\text { Manual_ } \\
\text { dec_relb }\end{array}$ & $\begin{array}{r}\text { Manual_- } \\
\text { inc_relv }\end{array}$ \\
\hline SFAS042 & Determining M ateriality for Capitalization of Interest Cost: an amendment of FASB Statement No. 34 & $04 / 22 / 80$ & 0.000 & 0.000 & 0.000 & 0.000 \\
\hline SFAS043 & Accounting for Compensated Absences & $12 / 17 / 79$ & 0.050 & 0.000 & 0.000 & 0.000 \\
\hline SFAS044 & $\begin{array}{l}\text { Accounting for Intangible Assets of Motor Carriers: an amendment of Chapter } 5 \text { of ARB } 43 \text { and an } \\
\text { interpretation of APB Opinions } 17 \text { and } 30\end{array}$ & $10 / 24 / 80$ & 0.000 & 0.000 & 0.000 & 0.000 \\
\hline \begin{tabular}{|l|} 
SFAS045 \\
\end{tabular} & Accounting for Franchise Fee Revenue & \begin{tabular}{l|}
$12 / 01 / 80$ \\
\end{tabular} & 0.000 & 0.000 & NA & NA \\
\hline SFAS046 & Financial Reporting and Changing Prices: Motion Picture Films; a supplement to FASB Statement No. 33 & $02 / 09 / 81$ & 0.000 & 0.057 & 0.000 & 0.000 \\
\hline SFAS047 & $\begin{array}{l}\text { Disclosure of Guarantees, Project Financing Arrangements, and Other Similar Obligations: an amendment } \\
\text { of FASB Statement No. } 5\end{array}$ & $03 / 31 / 80$ & 0.000 & 0.000 & 0.000 & 0.000 \\
\hline SFAS047 & $\begin{array}{l}\text { Disclosure of Obligations: I Disclosure of Indirect Guarantees of Indebtedness of Others: an } \\
\text { interp retation of FASB Statement No. } 5\end{array}$ & $11 / 14 / 80$ & NA & $\mathrm{NA}$ & 0.000 & 0.000 \\
\hline $\begin{array}{l}\text { SFAS048 } \\
\text { /SFAS049 }\end{array}$ & $\begin{array}{l}\text { Accounting for Certain Product Sales I Revenue Recognition When Right of Return Exists II Accounting } \\
\text { for Product Financing Arrangements }\end{array}$ & $02 / 09 / 81$ & 0.000 & 0.000 & NA & NA \\
\hline $\begin{array}{l}\text { SFAS050 } \\
\text { /SFAS051 } \\
\text { /SFAS053 } \\
\text { /SFAS063 }\end{array}$ & $\begin{array}{l}\text { Accounting by the Entertainment Industry I Motion Picture Films II Broadcasting III Cable Television } \\
\text { IV Records \& Music }\end{array}$ & $06 / 12 / 81$ & 0.000 & 0.000 & $\mathrm{NA}$ & NA \\
\hline SFAS052 & Foreign Currency Translation & $08 / 28 / 80$ & NA & NA & 0.000 & 0.000 \\
\hline SFAS052 & Foreign Currency Translation; revision of exposure draft issued August 28,1980 & $06 / 30 / 81$ & 0.104 & 0.000 & NA & NA \\
\hline SFAS054 & $\begin{array}{l}\text { Financial Reporting and Changing Prices: Investment Companies: an amendment of FASB Statement } \\
\text { No. } 33\end{array}$ & $11 / 16 / 81$ & 0.000 & 0.000 & 0.000 & 0.000 \\
\hline SFAS055 & $\begin{array}{l}\text { Determining whether a Convertible Security is a Common Stock Equivalent: an amendment of APB } \\
\text { Opinion No. } 15\end{array}$ & $11 / 06 / 81$ & 0.093 & 0.000 & 0.000 & 0.000 \\
\hline SFAS056 & $\begin{array}{l}\text { Applicability of FASB Statement No. } 32 \text { to AICPA Statements of Position and Guides on Accounting } \\
\text { and Auditing Matters: an amendment of FASB Statement No. } 32\end{array}$ & $11 / 06 / 81$ & 0.000 & 0.000 & 1.000 & 0.000 \\
\hline SFAS057 & Related Party Disclosures & $11 / 06 / 81$ & 0.125 & 0.000 & 0.000 & 0.000 \\
\hline SFAS058 & $\begin{array}{l}\text { Capitalization of Interest Cost in Financial Statements That Include Investments Accounted for by The } \\
\text { Equity Method; an amendment of FASB }\end{array}$ & $09 / 30 / 81$ & 0.000 & 0.000 & 0.000 & 0.000 \\
\hline SFAS059 & $\begin{array}{l}\text { Deferral of the Effective Date of Certain Accounting Requirements for Pension Plans of State and Local } \\
\text { Governmental Units: an amendment of FASB Statement No. } 35\end{array}$ & $02 / 22 / 82$ & 0.000 & 0.000 & 0.000 & 0.000 \\
\hline \begin{tabular}{|l|l|} 
SFAS060 \\
/SFAS061
\end{tabular} & $\begin{array}{l}\text { Accounting by the Insurance Industry I Accounting and Reporting by Insurance Enterprises II } \\
\text { Accounting for Title Plant }\end{array}$ & $11 / 18 / 81$ & 0.000 & 0.000 & 0.000 & 0.000 \\
\hline SFAS062 & $\begin{array}{l}\text { Capitalization of Interest Cost in Situations Involving Tax-Exempt Borrowings and Certain Gifts and } \\
\text { Grants: an amendment of FASB Statement No. } 34\end{array}$ & $12 / 22 / 81$ & 0.000 & 0.000 & 1.000 & 0.000 \\
\hline SFAS064 & $\begin{array}{l}\text { Extinguishment of Debt Made to Satisfy Sinking-Fund Requirements: an amendment of FASB Statement } \\
\text { No. } 4\end{array}$ & $02 / 23 / 82$ & 0.000 & 0.000 & 0.000 & 0.000 \\
\hline \begin{tabular}{|l|} 
SFAS065 \\
\end{tabular} & Accounting for Certain M ortgage Banking Activities & $02 / 03 / 82$ & 0.000 & 0.000 & 0.000 & 0.000 \\
\hline $\begin{array}{l}\text { SFAS066 } \\
\text { /SFAS067 }\end{array}$ & $\begin{array}{l}\text { Accounting for Certain Real Estate Transactions I Accounting for Costs and Initial Rental Operations of } \\
\text { Real Estate Projects II Accounting for Sales of Real Estate }\end{array}$ & $12 / 15 / 81$ & 0.000 & 0.000 & 0.000 & 0.000 \\
\hline SFAS068 & Research and Development Arrangements & $04 / 27 / 82$ & 0.000 & 0.000 & 1.000 & 0.000 \\
\hline SFAS069 & Disclosures about Oil and Gas Producing Activities: an amendment of FASB Statements 19 and 25 & $04 / 15 / 82$ & 0.000 & 0.000 & 0.000 & 1.000 \\
\hline SFAS070 & $\begin{array}{l}\text { Financial Reporting and Changing Prices: Foreign Currency Translation: an amendment of FASB } \\
\text { Statement No. } 33\end{array}$ & $12 / 22 / 81$ & NA & NA & 0.000 & 0.000 \\
\hline SFAS070 & $\begin{array}{l}\text { Financial Rep orting and Changing Prices: Foreign Currency Translation: an amendment of FASB } \\
\text { Statement No. } 33 \text { (Revision of } 12 / 22 / 81 \text { ED }\end{array}$ & $08 / 19 / 82$ & 0.000 & 0.000 & 0.000 & 0.000 \\
\hline SFAS071 & Accounting for the Effects of Regulation of an Enterp rise's Prices Based on Its Costs & $03 / 04 / 82$ & 0.061 & 0.000 & 1.000 & 0.000 \\
\hline SFAS072 & $\begin{array}{l}\text { Accounting for Certain Acquisitions of Banking or Thrift Institutions: an amendment of APB Opinion No. } \\
17 \text { and an interpretation of APB Opinion No. } 16\end{array}$ & $10 / 07 / 82$ & 0.000 & 0.000 & 0.000 & 0.000 \\
\hline SFAS073 & Reporting a Change in Accounting for Railroad Track Structures: an amendment of APB Opinion No. 20 & $04 / 12 / 83$ & 0.000 & 0.000 & 0.000 & 0.000 \\
\hline SFAS074 & Accounting for Special Termination Benefits Paid to Employees & $12 / 28 / 82$ & 0.000 & 0.000 & 1.000 & 0.000 \\
\hline SFAS075 & $\begin{array}{l}\text { Deferral of the Effective Date of Certain Accounting Requirements for Pension Plans of State and Local } \\
\text { Governmental Units: an amendment of FASB Statement No. } 35\end{array}$ & $06 / 07 / 83$ & 0.000 & 0.000 & 0.000 & 0.000 \\
\hline SFAS076 & $\begin{array}{l}\text { Extinguishment of Debt and the Offsetting of Restricted Assets against Related Debt: an amendment of } \\
\text { APB Opinion No. } 26 \text { and FASB Statement No. } 34\end{array}$ & $10 / 13 / 82$ & NA & NA & 0.000 & 0.000 \\
\hline SFAS076 & Extinguishment of Debt: an amendment of APB Opinion No. 26 (Revision of 10/31/82 ED) & $07 / 14 / 83$ & 0.000 & 0.000 & 0.000 & 0.000 \\
\hline SFAS077 & Accounting and Reporting by Transferors for Transfers of Receivables with Recourse & $11 / 18 / 81$ & NA & NA & 0.000 & 0.000 \\
\hline SFAS077 & Reporting by Transferors for Transfers of Receivables with Recourse (Revision of 11/18/81 ED) & $08 / 31 / 82$ & 0.000 & 0.000 & 0.000 & 0.000 \\
\hline SFAS078 & $\begin{array}{l}\text { Classification of Obligations That Are Callable by the Creditor: an amendment of Chapter 3A of ARB No. } \\
43\end{array}$ & $07 / 30 / 82$ & 0.000 & 0.000 & 0.000 & 0.000 \\
\hline SFAS079 & $\begin{array}{l}\text { Elimination of Certain Disclosures for Business Combinations by Nonpublic Enterprises: an amendment } \\
\text { of APB Opinion No. } 16\end{array}$ & $10 / 04 / 83$ & 0.000 & 0.000 & 0.000 & 0.000 \\
\hline SFAS080 & Accounting for Futures Contracts & $07 / 14 / 83$ & 0.239 & 0.000 & 0.000 & 2.000 \\
\hline SFAS081 & Disclosure of Postretirement Health Care and Life Insurance Benefits Information & $07 / 03 / 84$ & 0.000 & 0.000 & 0.000 & 0.000 \\
\hline SFAS082 & $\begin{array}{l}\text { Financial Reporting and Changing Prices: Elimination of Certain Disclosures: an amendment of FASB } \\
\text { Statement No. } 33\end{array}$ & $10 / 10 / 84$ & 0.000 & 0.000 & 0.000 & 0.000 \\
\hline SFAS083 & $\begin{array}{l}\text { Designation of AICPA Guides and Statement of Position on Accounting by Brokers and Dealers in } \\
\text { Securities, by Employee Benefit Plans, and by Banks as Preferable for Purposes of Apply ing APB } \\
\text { Opinion 20: an amendment of FASB Statement No. } 32 \text { and a rescission of FASB Interpretation No. } 10\end{array}$ & $12 / 06 / 84$ & 0.000 & 0.000 & $\mathrm{NA}$ & NA \\
\hline SFAS084 & Induced Conversions of Convertible Debt: an amendment of APB Opinion No. 26 & $12 / 06 / 84$ & 0.000 & 0.000 & 0.000 & 0.000 \\
\hline SFAS085 & $\begin{array}{l}\text { Yield Test for Determining whether a Convertible Security is a Common Stock Equivalent: an amendment } \\
\text { of APB Opinion No. } 15\end{array}$ & $12 / 06 / 84$ & 0.000 & 0.000 & 0.000 & 0.000 \\
\hline
\end{tabular}




\section{Appendix D ...Cont.}

\begin{tabular}{|c|c|c|c|c|c|c|}
\hline SFAS & ED Title & ED Date & dec_relb & inc_relv & $\begin{array}{r}\text { Manual_ } \\
\text { dec_relb }\end{array}$ & $\begin{array}{c}\text { Manual_ } \\
\text { inc_relv }\end{array}$ \\
\hline SFAS086 & Accounting for the Costs of Computer Software to Be Sold, Leased, or Otherwise Marketed & $08 / 31 / 84$ & 0.471 & 0.000 & 1.000 & 2.000 \\
\hline SFAS087 & Employers' Accounting for Pensions & $03 / 22 / 85$ & 0.096 & 0.000 & $\mathrm{NA}$ & NA \\
\hline SFAS088 & $\begin{array}{l}\text { Employers' Accounting for Settlements and Curtailments of Defined Benefit Pension Plans and for } \\
\text { Termination Benefits }\end{array}$ & $06 / 14 / 85$ & 0.000 & 0.000 & 0.000 & 0.000 \\
\hline SFAS089 & Financial Reporting and Changing Prices: Current Cost Information & $12 / 14 / 84$ & $\mathrm{NA}$ & $\mathrm{NA}$ & 0.000 & 0.000 \\
\hline SFAS089 & Financial Reporting and Changing Prices & $09 / 30 / 86$ & NA & NA & 0.000 & 0.000 \\
\hline $\begin{array}{l}\text { SFAS090 } \\
\text { /SFAS092 }\end{array}$ & $\begin{array}{l}\text { Regulated Enterprises -- Accounting for Phase-in Plans, Abandonments, and Disallowances of Plant } \\
\text { Costs: an amendment of FASB Statement No. } 71\end{array}$ & $12 / 19 / 85$ & 0.000 & 0.000 & NA & NA \\
\hline SFAS091 & $\begin{array}{l}\text { Accounting for Nonrefundable Fees and Costs Associated with Originating and Acquiring Loans: an } \\
\text { amendment of FASB Statements } 13,60 \text {, and } 65 \text { and a rescission of FASB Statement No. } 17\end{array}$ & $12 / 31 / 85$ & 0.000 & 0.000 & 0.000 & 0.000 \\
\hline SFAS093 & Recognition of Depreciation by Not-for-Profit Organizations & $12 / 23 / 86$ & 0.000 & 0.000 & 0.000 & 0.000 \\
\hline SFAS094 & $\begin{array}{l}\text { Consolidation of All Majority-Owned Subsidiaries-an amendment of ARB No. 51, with related } \\
\text { amendments of APB Opinion No. } 18 \text { and ARB No. 43, Chapter } 12\end{array}$ & $12 / 16 / 86$ & 0.000 & 0.013 & 0.000 & 0.000 \\
\hline SFAS095 & Reporting Income, Cash Flows, and Financial Position of Business Enterprises & $11 / 16 / 81$ & $\mathrm{NA}$ & $\mathrm{NA}$ & 0.000 & 0.000 \\
\hline SFAS095 & Statement of Cash Flows & $07 / 31 / 86$ & 0.000 & 0.122 & 0.000 & 0.000 \\
\hline SFAS096 & Accounting for Income Taxes & $09 / 02 / 86$ & 0.023 & 0.157 & 0.000 & 0.000 \\
\hline SFAS097 & $\begin{array}{l}\text { Accounting and Reporting by Insurance Enterp rises for Certain Long-Duration Insurance Contracts and } \\
\text { for Realized Gains and Losses from the Sale of Investments }\end{array}$ & $12 / 23 / 86$ & 0.000 & 0.000 & 1.000 & 0.000 \\
\hline SFAS098 & $\begin{array}{l}\text { Sale and Leaseback Transactions Involving Real Estate, Sales-Type Leases of Real Estate, Definition of } \\
\text { the Lease Term, and Initial Direct Costs of Direct Financing Leases }\end{array}$ & $08 / 31 / 87$ & NA & NA & 0.000 & 0.000 \\
\hline SFAS099 & Deferral of the Effective Date of Recognition of Depreciation by Not-for-Profit Organizations & $06 / 06 / 88$ & 0.000 & 0.000 & 0.000 & 0.000 \\
\hline SFAS100 & $\begin{array}{l}\text { Accounting for Income Taxes-Deferral of the Effective Date of FASB Statement No. 96: an amendment } \\
\text { of FASB Statement No. } 96\end{array}$ & $10 / 13 / 88$ & 0.000 & 0.000 & 0.000 & 0.000 \\
\hline SFAS101 & Regulated Enterprises-Accounting for the Discontinuation of Application of FASB Statement No. 71 & $07 / 08 / 88$ & NA & $\mathrm{NA}$ & 0.000 & 0.000 \\
\hline SFAS102 & $\begin{array}{l}\text { Statement of Cash Flows-Exemption of Certain Enterprises and Classification of Cash Flows from } \\
\text { Certain Securities Held for Resale }\end{array}$ & $11 / 30 / 88$ & 0.000 & 0.000 & 0.000 & 0.000 \\
\hline SFAS103 & $\begin{array}{l}\text { Accounting for Income Taxes-Deferral of the Effective Date of FASB Statement No. 96: an amendment } \\
\text { of FASB Statement No. } 96\end{array}$ & $10 / 19 / 89$ & NA & $\mathrm{NA}$ & NA & NA \\
\hline SFAS104 & $\begin{array}{l}\text { Statement of Cash Flows-Net Reporting of Certain Cash Receipts and Cash Payments and Classification } \\
\text { of Cash Flows from Hedging Transactions }\end{array}$ & $07 / 25 / 89$ & 0.000 & 0.151 & 0.000 & 0.000 \\
\hline SFAS105 & Disclosure about Financial Instruments & $11 / 30 / 87$ & NA & $\mathrm{NA}$ & 1.000 & 1.000 \\
\hline SFAS105 & $\begin{array}{l}\text { Disclosure of Information about Financial Instruments with Off-Balance-Sheet Risk and Financial } \\
\text { instruments with Concentrations of Credit Risk }\end{array}$ & $07 / 21 / 89$ & 0.000 & 0.000 & 0.000 & 0.000 \\
\hline SFAS106 & Employers' Accounting for Postretirement Benefits Other Than Pensions & $02 / 14 / 89$ & 0.533 & 0.000 & 1.000 & 4.000 \\
\hline SFAS107 & Disclosures about Market Value of Financial Instruments & $12 / 31 / 90$ & 0.244 & 0.593 & 1.000 & 1.000 \\
\hline SFAS108 & $\begin{array}{l}\text { Accounting for Income Taxes-Deferral of the Effective Date of Statement No. 96, an amendment of } \\
\text { FASB Statement No. } 96\end{array}$ & $06 / 17 / 91$ & 0.000 & 0.000 & 0.000 & 0.000 \\
\hline SFAS109 & Accounting for Income Taxes & $06 / 05 / 91$ & NA & NA & 0.000 & 0.000 \\
\hline SFAS110 & $\begin{array}{l}\text { Reporting by Defined Benefit Pension Plans of Investment Contracts: an amendment of FASB Statement } \\
\text { No. } 35\end{array}$ & $03 / 20 / 92$ & 0.000 & 0.326 & 1.000 & 1.000 \\
\hline SFAS111 & Rescission of FASB Statement No. 32 and Technical Corrections & $06 / 30 / 92$ & 0.000 & 0.000 & 0.000 & 0.000 \\
\hline SFAS112 & Employers' Accounting for Postretirement Benefits: an amendment of FASB Statements No. 5 and 43 & $05 / 12 / 92$ & 0.000 & 0.000 & 0.000 & 0.000 \\
\hline SFAS113 & Accounting and Reporting for Reinsurance of Short-Duration and Long-Duration Contracts & $03 / 20 / 92$ & 0.049 & 0.121 & 0.000 & 0.000 \\
\hline SFAS114 & Accounting by Creditors for Impairment of a Loan: an amendment of FASB Statements No. 5 and 15 & $06 / 30 / 92$ & 0.210 & 0.124 & 1.000 & 2.000 \\
\hline SFAS115 & Accounting for Certain Investments in Debt and Equity Securities & $09 / 09 / 92$ & 0.507 & 0.000 & 1.000 & 4.000 \\
\hline SFAS116 & $\begin{array}{l}\text { Accounting for Contributions Received and Contributions Made and Capitalization of Works of Art, } \\
\text { Historical Treasurers, and Similar Assets }\end{array}$ & $10 / 31 / 90$ & 0.000 & 0.000 & 1.000 & 2.000 \\
\hline SFAS116 & Accounting for Contributions Received and Contributions Made (Revision of 10/31/90 ED) & $11 / 17 / 92$ & 0.379 & 0.000 & 1.000 & 0.000 \\
\hline SFAS117 & Financial Statements of Not-for-Profit Organizations & $10 / 23 / 92$ & 0.000 & 0.589 & 0.000 & 0.000 \\
\hline SFAS118 & $\begin{array}{l}\text { Accounting by Creditors for Impairment of a Loan-Income Recognition: an amendment of FASB } \\
\text { Statement No. } 114\end{array}$ & $03 / 31 / 94$ & 0.000 & 0.000 & 0.000 & 0.000 \\
\hline SFAS119 & Disclosure about Derivative Financial Instruments and Fair Value of Financial Instruments & $04 / 14 / 94$ & 0.000 & 0.137 & 0.000 & 1.000 \\
\hline SFAS120 & $\begin{array}{l}\text { Accounting and Reporting by Mutual Life Insurance Enterp rises and by Insurance Enterprises for Certain } \\
\text { Long-Duration Participating Contracts: an amendment of FASB Statements No. 60, 97, and } 113 \text { (Includes } \\
\text { Proposed AICPA Statement of Position, Accounting for Certain Insurance Activities of Mutual Life } \\
\text { Insurance Enterprises) }\end{array}$ & $03 / 24 / 94$ & 0.000 & 0.000 & 0.000 & 0.000 \\
\hline SFAS121 & Accounting for the Impairment of Long-Lived Assets & $11 / 29 / 93$ & 0.000 & 0.000 & 1.000 & 3.000 \\
\hline SFAS122 & $\begin{array}{l}\text { Accounting for Mortgage Servicing Rights and Excess Servicing Receivables and for Securitization of } \\
\text { Mortgage Loans an amendment of FASB Statement No. } 65\end{array}$ & $06 / 28 / 94$ & 0.148 & 0.030 & 1.000 & 4.000 \\
\hline SFAS123 & Accounting for Stock-Based Compensation & $06 / 30 / 93$ & 0.372 & 0.000 & 1.000 & 2.000 \\
\hline SFAS123R & Share-Based Payment: an amendment of FASB Statements No. 123 and 95 & $03 / 31 / 04$ & 0.318 & 0.466 & 0.000 & 2.000 \\
\hline SFAS124 & Accounting for Certain Investments Held by Not-for-Profit Organizations & $03 / 31 / 95$ & NA & $\mathrm{NA}$ & 0.000 & 3.000 \\
\hline
\end{tabular}




\section{Appendix D ...Cont.}

\begin{tabular}{|c|c|c|c|c|c|c|}
\hline SFAS & ED Title & ED Date & dec_relb & inc_relv & $\begin{array}{c}\text { Manual_ } \\
\text { dec_relb }\end{array}$ & $\begin{array}{l}\text { Manual_ } \\
\text { inc_relv }\end{array}$ \\
\hline SFAS125 & Accounting for Transfers and Servicing of Financial Assets and Extinguishments of Liabilities & $10 / 24 / 95$ & 0.510 & 0.120 & 1.000 & 2.000 \\
\hline SFAS126 & $\begin{array}{l}\text { Elimination of Certain Disclosures abut Financial Instruments by Small Nonpublic Entities: an amendment } \\
\text { of FASB Statement No. } 107\end{array}$ & $09 / 20 / 96$ & 0.000 & 0.000 & 0.000 & 0.000 \\
\hline SFAS127 & $\begin{array}{l}\text { Deferral of the Effective Date of Certain Provisions of FASB Statement No. 125: an amendment of FASB } \\
\text { Statement No. } 125\end{array}$ & $11 / 11 / 96$ & 0.000 & 0.000 & 0.000 & 0.000 \\
\hline $\begin{array}{l}\text { SFAS128 } \\
\text { /SFAS129 } \\
\end{array}$ & Earnings per Share and Disclosure of Information about Capital Structure & $01 / 19 / 96$ & 0.000 & 0.135 & 0.000 & 0.000 \\
\hline SFAS130 & Reporting Comprehensive Income & $06 / 20 / 96$ & 0.000 & 0.000 & 0.000 & 0.000 \\
\hline SFAS131 & Reporting Disaggregated Information about a Business Enterp rise & $01 / 19 / 96$ & 0.018 & 0.000 & 1.000 & 0.000 \\
\hline SFAS132 & $\begin{array}{l}\text { Emp loy ers' Disclosures about Pensions and Other Postretirement Benefits: an amendment of FASB } \\
\text { Statements No. } 87,88 \text {, and } 106\end{array}$ & $06 / 30 / 97$ & 0.000 & 0.000 & 0.000 & 1.000 \\
\hline SFAS132R & $\begin{array}{l}\text { Employers' Disclosures about Pensions and Other Postretirement Benefits: an amendment of FASB } \\
\text { Statements No. 87, 88, and } 106 \text { and a replacement of FASB Statement No. } 132\end{array}$ & $09 / 12 / 03$ & 0.163 & 0.131 & 0.000 & 1.000 \\
\hline SFAS133 & Accounting for Derivative and Similar Financial Instruments and for Hedging Activities & $06 / 20 / 96$ & 0.101 & 0.046 & 1.000 & 3.000 \\
\hline SFAS134 & $\begin{array}{l}\text { Accounting for Mortgage-Backed Securities and Certain Other Interests Retained after the Securitization } \\
\text { of Mortgage Loans Held for Sale by a Mortgage Banking Enterprise: an amendment of FASB Statement } \\
\text { No. } 65\end{array}$ & $4 / 10 ; 98$ & 0.000 & 0.000 & 1.000 & 2.000 \\
\hline SFAS135 & $\begin{array}{l}\text { Amendments to FASB Statement No. 66, Rescission of FASB Statement No. 75, and Technical } \\
\text { Corrections }\end{array}$ & $10 / 13 / 98$ & 0.000 & 0.000 & 0.000 & 0.000 \\
\hline SFAS136 & $\begin{array}{l}\text { Transfers of Assets in Which a Not-for-Profit Organization Acts as an Agent, Trustee, or Intermediary: an } \\
\text { Interpretation of FASB Statement No. } 116\end{array}$ & $12 / 29 / 95$ & NA & NA & 0.000 & 0.000 \\
\hline SFAS136 & $\begin{array}{l}\text { Transfers of Assets involving a Not-for-Profit Organization That Raises or Holds Contributions for } \\
\text { Others }\end{array}$ & $07 / 17 / 98$ & 0.000 & 0.000 & 0.000 & 3.000 \\
\hline SFAS137 & $\begin{array}{l}\text { Accounting for Derivative Instruments and Hedging Activities-Deferral of the Elective Date of FASB } \\
\text { Statement No. 133: an amendment of FASB Statement No. } 133\end{array}$ & $05 / 20 / 99$ & 0.000 & 0.000 & 0.000 & 0.000 \\
\hline SFAS138 & $\begin{array}{l}\text { Accounting for Certain Derivative instruments and Certain Hedging Activities: an amendment of FASB } \\
\text { Statement No. } 133\end{array}$ & $03 / 03 / 00$ & 0.000 & 0.000 & 0.000 & 0.000 \\
\hline SFAS139 & Rescission of FASB Statement No. 53 & $10 / 16 / 98$ & 0.000 & 0.000 & 0.000 & 0.000 \\
\hline SFAS140 & Accounting for Transfers of Financial Assets: an amendment of FASB Statement No. 125 & $06 / 28 / 99$ & 0.378 & 0.000 & 1.000 & 2.000 \\
\hline $\begin{array}{l}\text { SFAS141 } \\
\text { /SFAS142 }\end{array}$ & Business Combinations and Intangible Assets & $09 / 07 / 99$ & 0.461 & 0.152 & 1.000 & 3.000 \\
\hline SFAS141R & Business Combinations: a replacement of FASB Statement No. 141 & $06 / 30 / 05$ & 0.909 & 0.477 & 1.000 & 5.000 \\
\hline SFAS142 & Business Combinations and Intangible Assets-Accounting for Goodwill (Revision of 9/7/99 ED) & $02 / 14 / 01$ & 0.647 & 0.041 & 1.000 & 3.000 \\
\hline SFAS143 & Accounting for Certain Liabilities Related to Closure or Removal of Long-Lived Assets & $02 / 07 / 96$ & 0.000 & 0.000 & 1.000 & 1.000 \\
\hline SFAS143 & Accounting for Obligations Associated with the Retirement of Long-Lived Assets (Revision of 2/7/96 ED) & $02 / 17 / 00$ & 0.452 & 0.278 & 1.000 & 0.000 \\
\hline $\begin{array}{l}\text { SFAS144 } \\
\text { /SFAS146 }\end{array}$ & Rescission of FASB Statements No. 4, 44, and 64 and Technical Corrections & $11 / 15 / 01$ & 0.158 & 0.376 & 1.000 & 2.000 \\
\hline SFAS145 & $\begin{array}{l}\text { Accounting for the Impairment or Disposal of Long-Lived Assets and for Obligations Associated with } \\
\text { Disposal Activities }\end{array}$ & $06 / 30 / 00$ & 0.000 & 0.000 & 0.000 & 0.000 \\
\hline SFAS145 & $\begin{array}{l}\text { Rescission of FASB Statements No. 4, 44, and } 64 \text { and Technical Corrections-Amendment of FASB } \\
\text { Statement No. } 13 \text { (Revision of 11/15/01 ED) }\end{array}$ & $02 / 14 / 02$ & 0.000 & 0.000 & 0.000 & 0.000 \\
\hline SFAS147 & $\begin{array}{l}\text { Acquisitions of Certain Financial Institutions: an amendment of FASB Statements No. } 72 \text { and No. } 144 \text { and } \\
\text { FASB Interpretation No. } 9\end{array}$ & $05 / 10 / 02$ & 0.000 & 0.000 & 1.000 & 3.000 \\
\hline SFAS148 & $\begin{array}{l}\text { Accounting for Stock-Based Compensation--Transition and Disclosure: and amendment of FASB } \\
\text { Statement No. } 123\end{array}$ & $10 / 04 / 02$ & 0.000 & 0.000 & 1.000 & 1.000 \\
\hline \begin{tabular}{|l} 
SFAS149 \\
\end{tabular} & Amendment of Statement 133 on Derivative Instruments and Hedging Activities & $05 / 01 / 02$ & 0.132 & 0.000 & 0.000 & 1.000 \\
\hline SFAS150 & Accounting for Financial Instruments with Characteristics of Liabilities: Equity, or Both & $10 / 27 / 00$ & 0.297 & 0.000 & 0.000 & 0.000 \\
\hline SFAS151 & Inventory Costs: an amendment of ARB No. 43, Chapter 4 & $12 / 15 / 03$ & 0.000 & 0.000 & 0.000 & 0.000 \\
\hline SFAS152 & Accounting for Real Estate Time-Sharing Transactions: an amendment of FASB Statements No. 66 and 67 & $02 / 20 / 03$ & 0.000 & 0.000 & 0.000 & 0.000 \\
\hline SFAS153 & Exchanges of Productive Assets: an amendment of ABP Opinion No. 29 & $12 / 15 / 03$ & 0.161 & 0.000 & 1.000 & 1.000 \\
\hline SFAS154 & $\begin{array}{l}\text { Accounting Changes and Error Corrections: a replacement of ABP Op inion No. } 20 \text { and FASB Statement } \\
\text { No. } 3\end{array}$ & $12 / 15 / 03$ & 0.000 & 0.000 & 1.000 & 0.000 \\
\hline SFAS155 & $\begin{array}{l}\text { Accounting for Certain Hybrid Financial Instruments: an amendment of FASB Statements No. } 133 \text { and } \\
140\end{array}$ & $08 / 11 / 05$ & 0.190 & 0.397 & 1.000 & 2.000 \\
\hline SFAS156 & $\begin{array}{l}\text { Qualify ing Special-Purpose Entities and Isolation of Transferred Assets: an amendment of FASB } \\
\text { Statement No. } 140\end{array}$ & $06 / 10 / 03$ & NA & NA & 1.000 & 0.000 \\
\hline SFAS156 & $\begin{array}{l}\text { Accounting for Servicing of Financial Assets: an amendment of FASB Statement No. } 140 \text { (Revision of } \\
6 / 10 / 03 \text { ED) }\end{array}$ & $08 / 11 / 05$ & 0.003 & 0.113 & 1.000 & 4.000 \\
\hline SFAS156 & $\begin{array}{l}\text { Accounting for Transfers of Financial Assets: an amendment of FASB Statement No. } 140 \text { (Revision of } \\
6 / 10 / 03 \text { ED) }\end{array}$ & $08 / 11 / 05$ & NA & NA & 1.000 & 0.000 \\
\hline SFAS157 & Fair Value M easurements & $06 / 23 / 04$ & 0.599 & 0.245 & 0.000 & 2.000 \\
\hline SFAS158 & $\begin{array}{l}\text { Employers' Accounting for Defined Benefit Pension and Other Postretirement Plans: an amendment of } \\
\text { FASB Statements No. } 87,88,106 \text {, and } 132(\mathrm{R})\end{array}$ & $03 / 31 / 06$ & 0.000 & 0.000 & 0.000 & 1.000 \\
\hline SFAS159 & $\begin{array}{l}\text { The Fair Value Option for Financial Assets and Financial Liabilities: Including an amendment of FASB } \\
\text { Statement No. } 115\end{array}$ & $01 / 25 / 06$ & 0.451 & 0.669 & 1.000 & 4.000 \\
\hline SFAS160 & $\begin{array}{l}\text { Consolidated Financial Statements, Including Accounting and Reporting of Noncontrolling Interests in } \\
\text { Subsidiaries: a replacement of ARB No. } 51\end{array}$ & $06 / 30 / 05$ & 0.586 & 0.000 & 1.000 & 4.000 \\
\hline
\end{tabular}




\section{Figure 1}

Average tenure of FASB members and SEC commissioners by proposed SFAS, 1973-2007

The sample is the 157 proposed SFAS issued between 1973 and 2007 on which the Big N auditors filed comment letters. Tenure FASB is an exposure draft (ED)-level measure of the average tenure in years of all extant FASB members. Tenure SEC is an ED-level measure of the average tenure in years of all extant SEC commissioners.

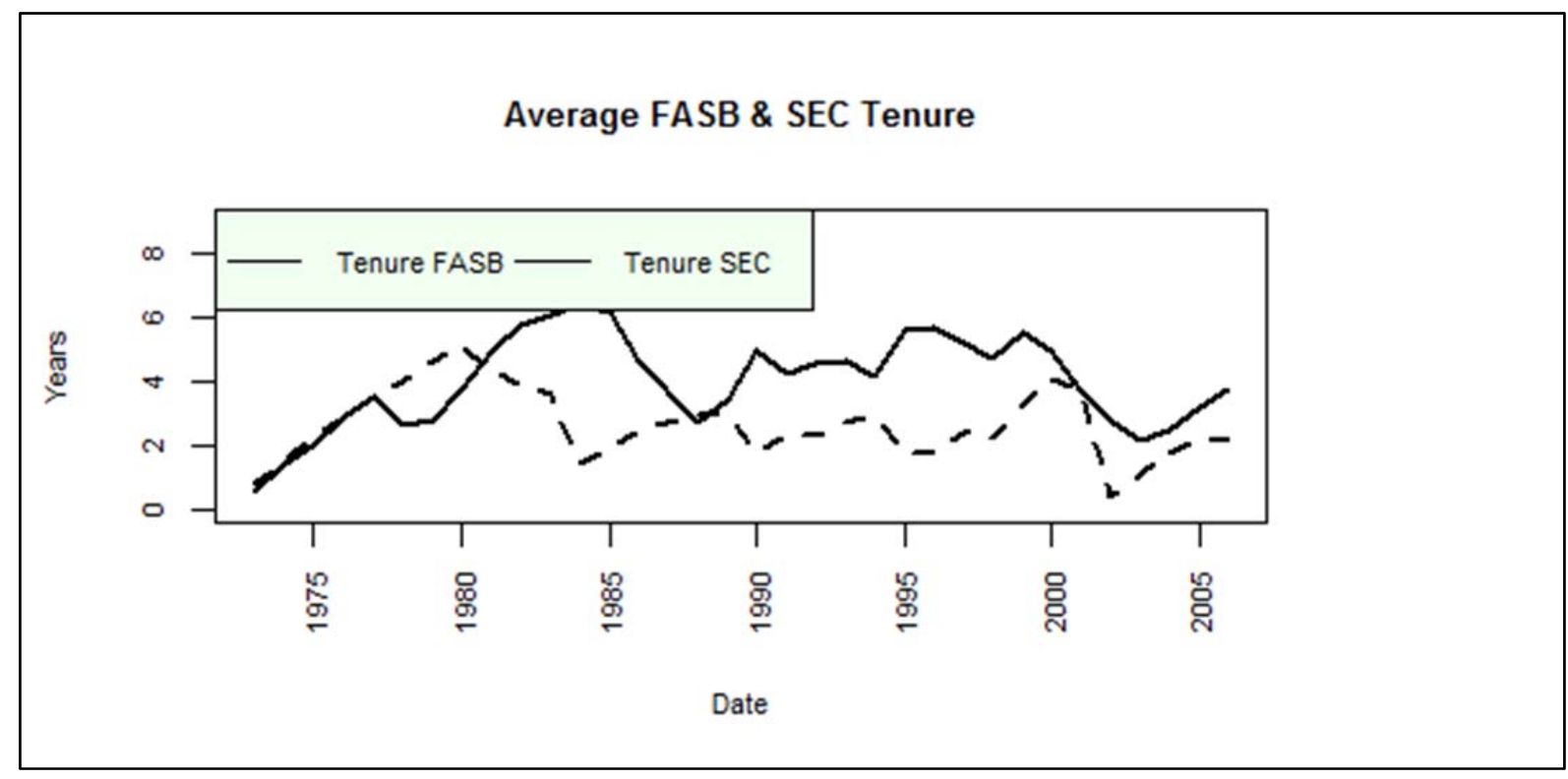




\section{Figure 2}

Proportion of FASB members and SEC commissioners with prior employment in auditing and financial services

The sample is the 157 proposed SFAS issued between 1973 and 2007 on which the Big N auditors filed comment letters. \% Auditor FASB is an ED-level measure of the proportion of extant FASB members with most recent former employ in auditing. \% Financial FASB is an ED-level measure of the proportion of extant FASB members with most recent former employ in investment banking/ investment management. \% Financial SEC is an ED-level measure of the proportion of extant SEC commissioners with most recent former employ in financial services.

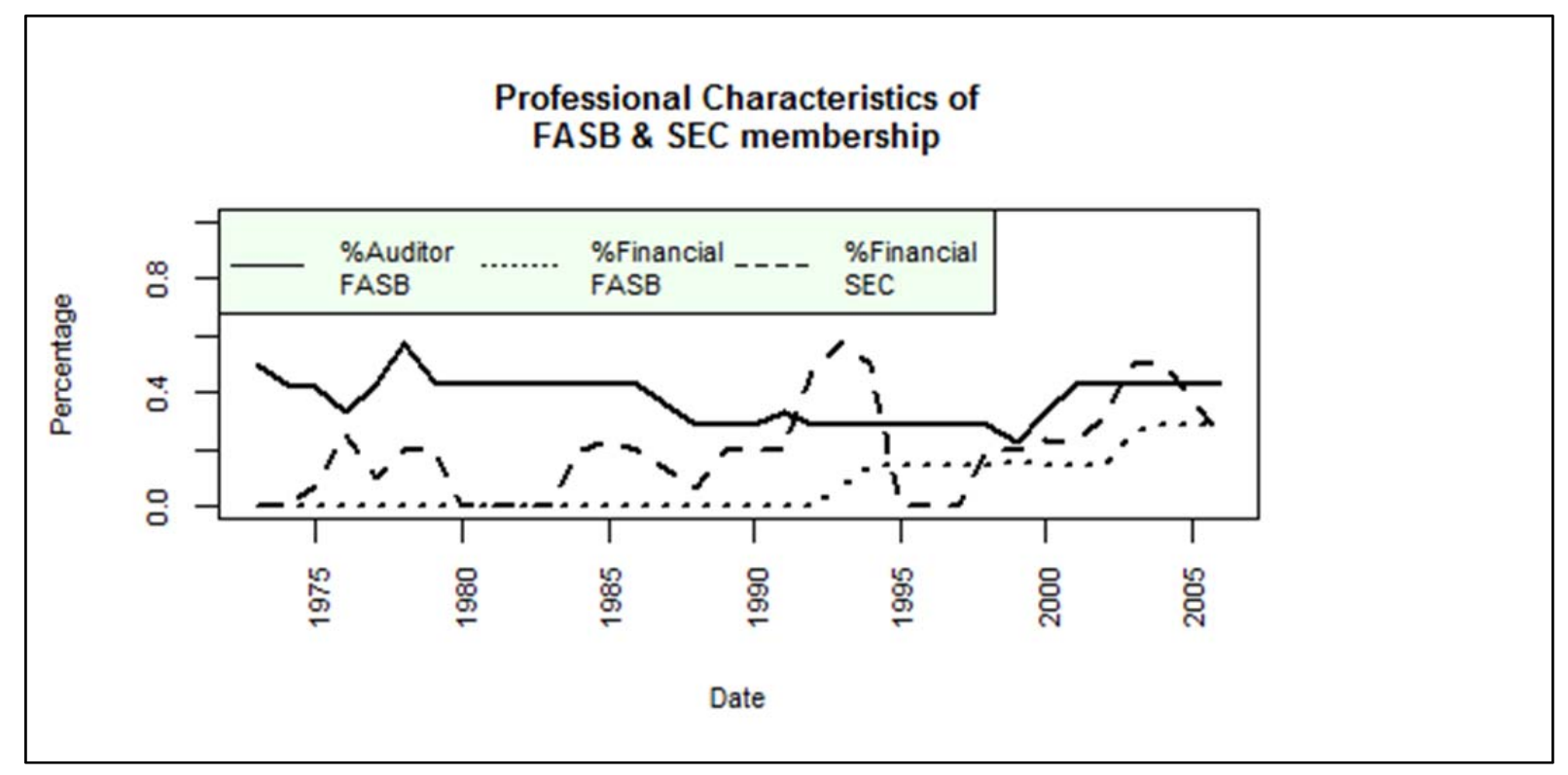




\section{Figure 3}

\section{Proportion of FASB members and SEC commissioners by political identity}

The sample is the 157 proposed SFAS issued between 1973 and 2007 on which the Big N auditors filed comment letters. \%Rep Donor FASB is an ED-level measure of the proportion of extant FASB members making campaign contributions to the Republican Party or candidates. \% Dem Donor FASB is an ED-level measure of the proportion of extant FASB members making campaign contributions to the Democratic Party or candidates. \% Democrat SEC is an ED-level measure of the proportion of extant Democratic SEC commissioners.

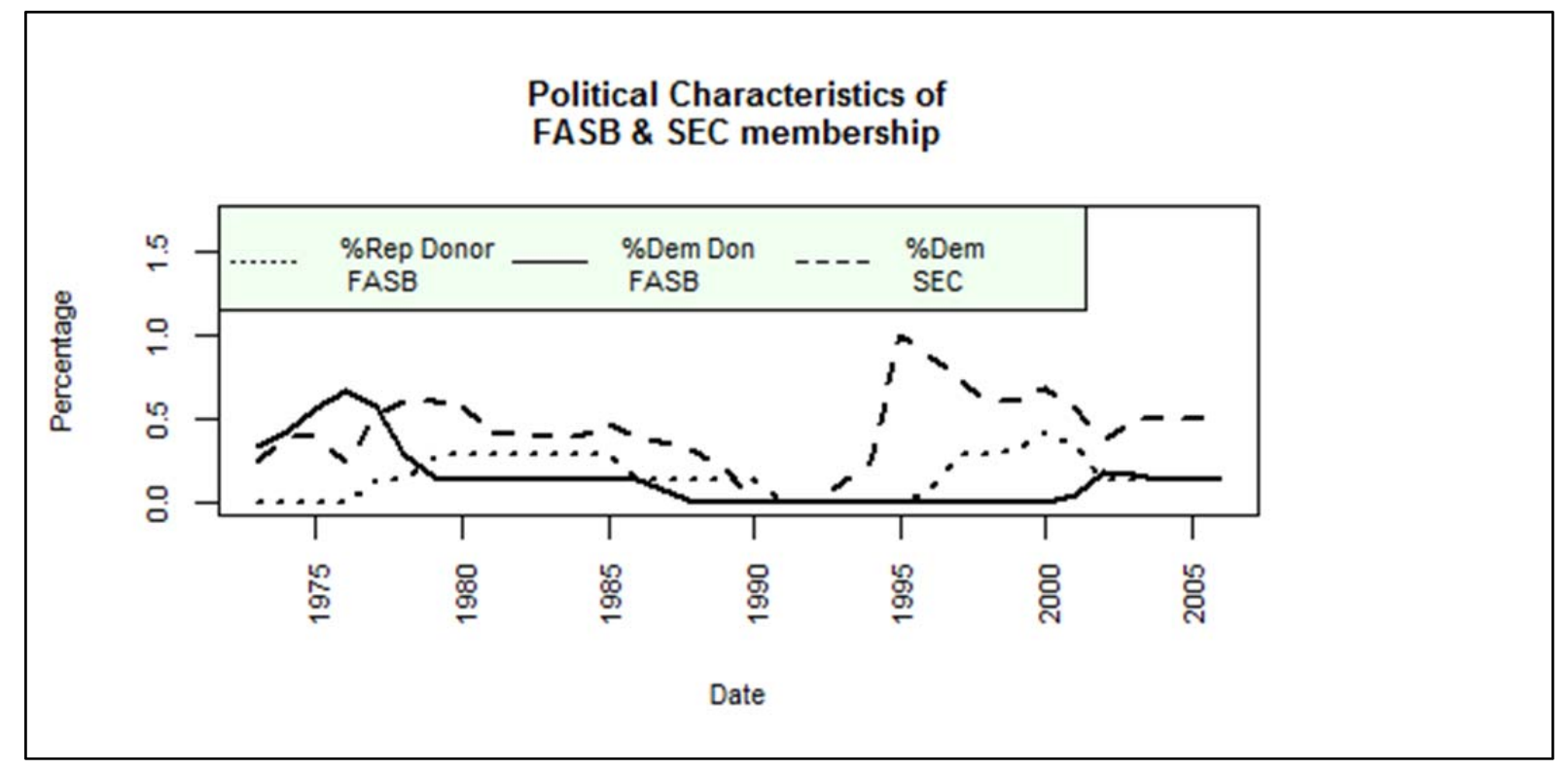




\section{Table 1}

\section{Big $\mathbf{N}$ auditor comment-letter availability}

The sample is the 157 proposed SFAS issued between 1973 and 2007 on which the Big N auditors filed comment letters.

\begin{tabular}{|c|c|c|c|c|}
\hline Era & Big 8 & Big 6 & Big 5 & Big 4 \\
\hline Period & 1973-1989 & 1989-1998 & $1998-2002$ & 2002-2007 \\
\hline \multirow[t]{6}{*}{ Audit Firms } & Arthur Anderson & Arthur Anderson & Arthur Anderson & \\
\hline & $\begin{array}{l}\text { Arthur Young } \\
\text { Ernst \& Whinney/ } \\
\text { Ernst \& Ernst }\end{array}$ & Ernst \& Young & Ernst \& Young & Ernst \& Young \\
\hline & $\begin{array}{l}\text { Touche Ross } \\
\text { Deloitte, Haskin \& Sells }\end{array}$ & Deloitte Touche & Deloitte Touche & Deloitte Touche \\
\hline & Peat Marwick & KPMG & KPMG & KPMG \\
\hline & Coopers Lybrand & Coopers Lybrand & PWC & PWC \\
\hline & Price Waterhouse & Price Waterhouse & & \\
\hline \# of SFAS issued & 104 & 30 & 10 & 19 \\
\hline \multirow[t]{2}{*}{ \# SFAS w/ zero CLs } & 4 & 2 & 0 & 0 \\
\hline & SFAS 89, 98, 101, 103 & SFAS 109, 124 & & \\
\hline Remaining Sample & 100 & 28 & 10 & 19 \\
\hline
\end{tabular}

The four proposed SFAS from 1973-1989 with no comment letters from the Big 8 are: SFAS 89 (which made supplementary information of price-level information voluntary); SFAS 98 (accounting for sale-leasebacks); SFAS 101 (disclosure issues in certain regulated entities); and SFAS 103 (resetting the effective date of another standard). The two proposed SFAS from 1989-1998 with no comment letters from the Big 6 are: SFAS 109 (re: accounting for income taxes) and SFAS 124 (re: accounting for certain investments held by non-profits). 


\section{Table 2}

\section{Summary statistics of and correlations between measures of decreased "reliability" and}

increased "relevance"

The sample is based on 157 proposed SFAS issued between 1973 and 2007. inc_relv is an assessment that a proposed SFAS will increase accounting "relevance" as expressed by the Big 8/6/5/4 auditors (hereafter "Big N auditors") in their comment letters. dec_relb is an assessment that a proposed SFAS will decrease accounting "reliability" as expressed by the Big N auditors in their comment letters. Manual_inc_relv is an assessment that a proposed SFAS will increase "relevance" as determined by two independent reviewers. Manual_dec_relb is an assessment that a proposed SFAS will decrease "reliability" as determined by two independent reviewers. See Section 3 for details.

\section{PANEL A: Summary statistics}

\begin{tabular}{lrrrrr}
\hline Variable & Mean & Median & \multicolumn{1}{c}{ S.D. } & Maximum & Minimum \\
\hline dec_relb & 0.07 & 0.00 & 0.22 & 0.99 & 0.00 \\
inc_relv & 0.04 & 0.00 & 0.17 & 0.98 & 0.00 \\
Manual_dec_relb & 0.31 & 0.00 & 0.46 & 1.00 & 0.00 \\
Manual_inc_relv & 0.65 & 0.00 & 1.20 & 5.00 & 0.00 \\
\hline
\end{tabular}

PANEL B: Pearson correlations (Spearman above the diagonal)

\begin{tabular}{llcccc}
\hline & Variable & $(1)$ & $(2)$ & $(3)$ & $(4)$ \\
\hline (1) dec_relb & 1.000 & $0.205^{* *}$ & $0.347^{* * *}$ & $0.502^{* * *}$ \\
(2) inc_relv & $0.225^{* * *}$ & $1.000^{* *}$ & $0.151^{*}$ & $0.238^{* * *}$ \\
(3) Manual_dec_relb & $0.341^{* * *}$ & $0.147^{*}$ & $1.000^{* *}$ & $0.596^{* * *}$ \\
(4) Manual_inc_relv & $0.502^{* * *}$ & $0.203^{* *}$ & $0.609^{* * *}$ & 1.000 \\
\hline
\end{tabular}

Significance levels: $(*) 10 \%$ level, $(* *) 5 \%$ level, $(* * *) 1 \%$ level using a 2 tailed test with S.E. clustered by SFAS 


\section{Table 3 Panel A}

\section{Summary statistics on explanatory variables}

The sample is based on the 157 proposed SFAS issued between 1973 and 2007 on which the Big N auditors filed comment letters. Tenure FASB is an ED-level measure of the average tenure in years of all extant FASB members. $\%$ Auditor FASB is an ED-level measure of the proportion of extant FASB members with most recent former employ in auditing. \% Financial FASB is an ED-level measure of the proportion of extant FASB members with most recent former employ in investment banking/ investment management. \%Rep Donor FASB is an ED-level measure of the proportion of extant FASB members making campaign contributions to the Republican Party or candidates. \% Dem Donor FASB is an ED-level measure of the proportion of extant FASB members making campaign contributions to the Democratic Party or candidates. Tenure SEC is an ED-level measure of the average tenure in years of all extant SEC commissioners. \% Financial SEC is an ED-level measure of the proportion of extant SEC commissioners with most recent former employ in financial services. \% Democrat SEC is an ED-level measure of the proportion of extant Democratic SEC commissioners.

\begin{tabular}{|c|c|c|c|c|c|}
\hline Variable & Mean & Median & S.D. & Maximum & Minimum \\
\hline \multicolumn{6}{|c|}{ FASB \& SEC Professional Characteristics } \\
\hline Tenure FASB & 4.2 & 4.3 & 1.5 & 6.7 & 0.6 \\
\hline$\%$ Auditor FASB & $39.52 \%$ & $42.86 \%$ & $7.80 \%$ & $57.14 \%$ & $16.67 \%$ \\
\hline$\%$ Financial FASB & $4.35 \%$ & $0.00 \%$ & $8.05 \%$ & $28.57 \%$ & $0.00 \%$ \\
\hline Tenure SEC & 3.1 & 3.0 & 1.2 & 6.2 & 0.2 \\
\hline \% Financial SEC & $15.15 \%$ & $20.00 \%$ & $16.62 \%$ & $66.67 \%$ & $0.00 \%$ \\
\hline \multicolumn{6}{|c|}{ FASB \& SEC Political Characteristics } \\
\hline \% Rep Donor FASB & $18.01 \%$ & $14.29 \%$ & $12.37 \%$ & $42.86 \%$ & $0.00 \%$ \\
\hline$\%$ Dem Donor FASB & $16.73 \%$ & $14.29 \%$ & $17.20 \%$ & $66.67 \%$ & $0.00 \%$ \\
\hline$\%$ Democrat SEC & $44.99 \%$ & $40.00 \%$ & $20.22 \%$ & $100.00 \%$ & $0.00 \%$ \\
\hline
\end{tabular}


Table 3 Panel B

\section{Pearson correlations between explanatory variables (Spearman above the diagonal)}

The sample is based on the 157 proposed SFAS issued between 1973 and 2007 on which the Big N auditors filed comment letters. Tenure FASB is an ED-level measure of the average tenure in years of all extant FASB members. \% Auditor FASB is an ED-level measure of the proportion of extant FASB members with most recent former employ in auditing. \% Financial FASB is an ED-level measure of the proportion of extant FASB members with most recent former employ in investment banking/ investment management. \%Rep Donor FASB is an ED-level measure of the proportion of extant FASB members making campaign contributions to the Republican Party or candidates. \% Dem Donor FASB is an ED-level measure of the proportion of extant FASB members making campaign contributions to the Democratic Party or candidates. Tenure SEC is an ED-level measure of the average tenure in years of all extant SEC commissioners. \% Financial SEC is an ED-level measure of the proportion of extant SEC commissioners with most recent former employ in financial services. \% Democrat SEC is an ED-level measure of the proportion of extant Democratic SEC commissioners.

FASB/SEC Professional Characteristics FASB/SEC Political Charac.

\begin{tabular}{|c|c|c|c|c|c|c|c|c|c|}
\hline & & \multicolumn{5}{|c|}{ FASB/SEC Professional Characteristics } & \multicolumn{3}{|c|}{ FASB/SEC Political Charac. } \\
\hline & & (1) & $(2)$ & (3) & (4) & (5) & (6) & (7) & $(8)$ \\
\hline & (1) Tenure FASB & 1.000 & $-0.255^{* * *}$ & 0.022 & 0.002 & $-0.155^{*}$ & $0.441^{* * *}$ & $-0.447^{* * *}$ & 0.020 \\
\hline $\mathrm{FASB} / \mathrm{SEC}$ & (2) $\%$ Auditor FASB & $-0.276 * * *$ & 1.000 & $-0.405 * * *$ & $0.295 * * *$ & $-0.175 * *$ & $0.229 * * *$ & $0.787 * * *$ & $0.175 * *$ \\
\hline Professional & (3) $\%$ Financial FASB & -0.035 & $-0.311 * * *$ & 1.000 & $-0.356 * * *$ & $0.351 * * *$ & -0.066 & $-0.448 * * *$ & $0.348 * * *$ \\
\hline Characteristics & (4) Tenure SEC & 0.053 & $0.282 * * *$ & $-0.365 * * *$ & 1.000 & $-0.306 * * *$ & $0.531^{* * *}$ & 0.093 & $0.193^{* *}$ \\
\hline & (5)\% Financial SEC & -0.122 & $-0.215 * * *$ & $0.403 * * *$ & $-0.320 * * *$ & 1.000 & $-0.222 * * *$ & $-0.245 * * *$ & $-0.146 *$ \\
\hline FASB/SEC & (6) \% Rep Donor FASB & $0.428^{* * *}$ & $0.216^{* * *}$ & -0.067 & $0.529^{* * *}$ & $-0.275^{* * *}$ & 1.000 & -0.108 & $0.346^{* * *}$ \\
\hline Political & (7) $\%$ Dem Donor FASB & $-0.521 * * *$ & $0.519 * * *$ & $-0.320 * * *$ & -0.030 & $-0.249 * * *$ & $-0.284 * * *$ & 1.000 & 0.052 \\
\hline Characteristics & (8) \% Democrat SEC & 0.068 & $0.149 *$ & $0.336^{* * *}$ & $0.135 *$ & $-0.341 * * *$ & $0.284 * * *$ & 0.022 & 1.000 \\
\hline
\end{tabular}




\section{Table 4}

\section{OLS regression of dec_relb on the characteristics of FASB members and SEC commissioners}

Sample is 908 big auditor comment letters written on 149 exposure drafts that became 157 SFAS issued between 1973 and 2007. dec_relb is an assessment that a proposed SFAS will decrease accounting "reliability" as expressed by the Big N auditors in their comment letters. See Section 3 for details. Tenure FASB is an ED-level measure of the average tenure in years of all extant FASB members. \% Auditor FASB is an ED-level measure of the proportion of extant FASB members with most recent former employ in auditing. \% Financial FASB is an ED-level measure of the proportion of extant FASB members with most recent former employ in investment banking/ investment management. \%Rep Donor FASB is an ED-level measure of the proportion of extant FASB members making campaign contributions to the Republican Party or candidates. \% Dem Donor FASB is an ED-level measure of the proportion of extant FASB members making campaign contributions to the Democratic Party or candidates. Tenure SEC is an ED-level measure of the average tenure in years of all extant SEC commissioners. \% Financial SEC is an ED-level measure of the proportion of extant SEC commissioners with most recent former employ in financial services. \% Democrat SEC is an ED-level measure of the proportion of extant Democratic SEC commissioners. The market variables are VWRETD and sd_VWRETD. VWRETD is the annual value-weighted market return (from CRSP) for the 12 months directly preceding the month in which a proposed SFAS was issued. sd_VWRETD is the standard deviation of daily VWRETD for the 12 months directly preceding the month in which a proposed SFAS was issued. Figures in italics and parentheses are standard errors.

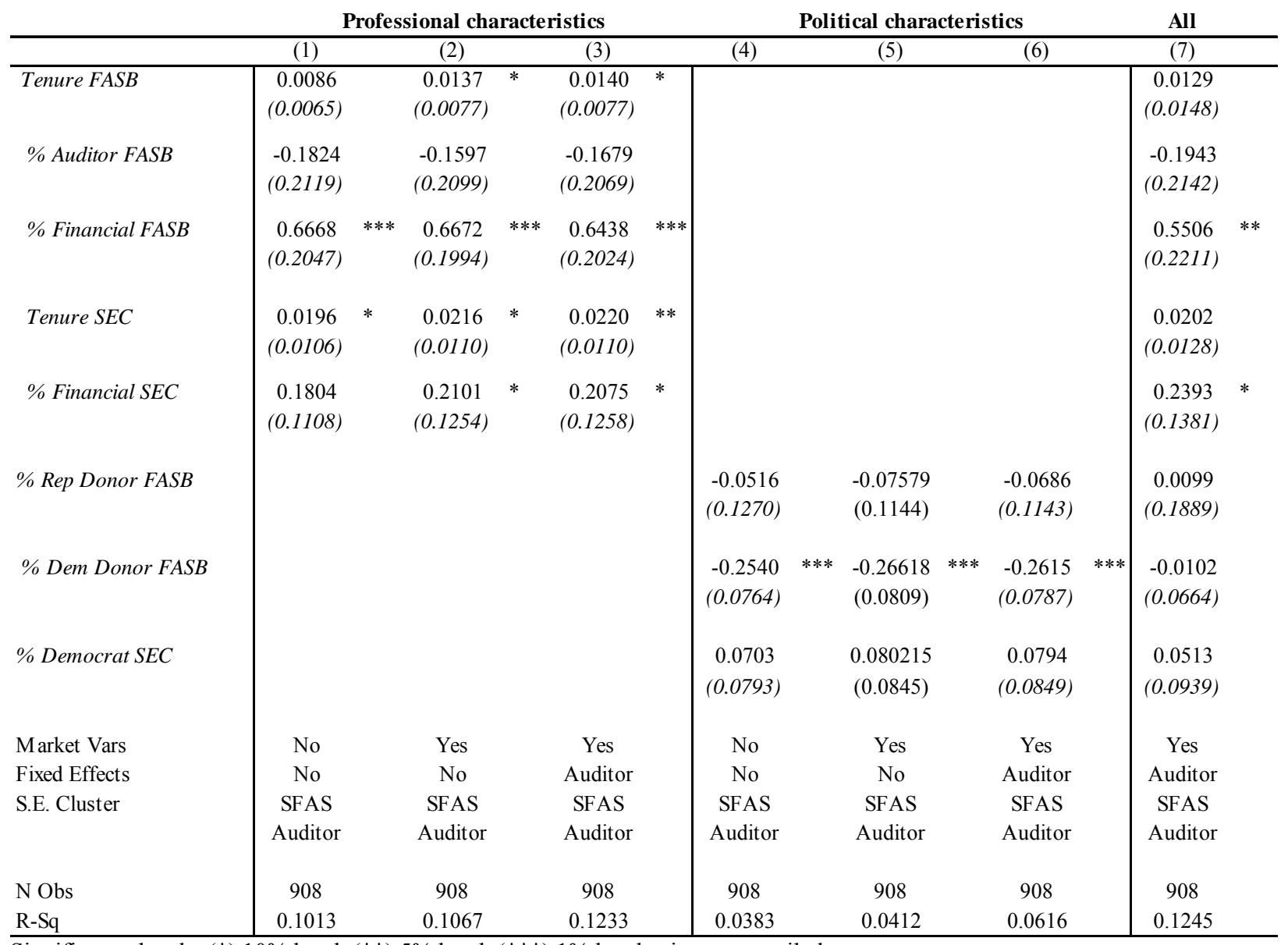

Significance levels: (*) 10\% level, (**) 5\% level, (***) 1\% level using a two-tailed t-test. 
Table 5

\section{OLS regression of inc_relv on the characteristics of FASB members and SEC commissioners}

Sample is 908 big auditor comment letters written on 149 exposure drafts that became 157 SFAS issued between 1973 and 2007. inc_relv is an assessment that a proposed SFAS will increase accounting "relevance" as expressed by the Big 8/6/5/4 auditors (hereafter "Big N auditors") in their comment letters. See Section 3 for details. Tenure FASB is an ED-level measure of the average tenure in years of all extant FASB members. \% Auditor FASB is an ED-level measure of the proportion of extant FASB members with most recent former employ in auditing. \% Financial FASB is an ED-level measure of the proportion of extant FASB members with most recent former employ in investment banking/ investment management. \%Rep Donor FASB is an ED-level measure of the proportion of extant FASB members making campaign contributions to the Republican Party or candidates. \% Dem Donor FASB is an ED-level measure of the proportion of extant FASB members making campaign contributions to the Democratic Party or candidates. Tenure SEC is an ED-level measure of the average tenure in years of all extant SEC commissioners. \% Financial SEC is an ED-level measure of the proportion of extant SEC commissioners with most recent former employ in financial services. \% Democrat SEC is an ED-level measure of the proportion of extant Democratic SEC commissioners. The market variables are VWRETD and sd_VWRETD. VWRETD is the annual value-weighted market return (from CRSP) for the 12 months directly preceding the month in which a proposed SFAS was issued. sd_VWRETD is the standard deviation of daily VWRETD for the 12 months directly preceding the month in which a proposed SFAS was issued. Figures in italics and parentheses are standard errors.

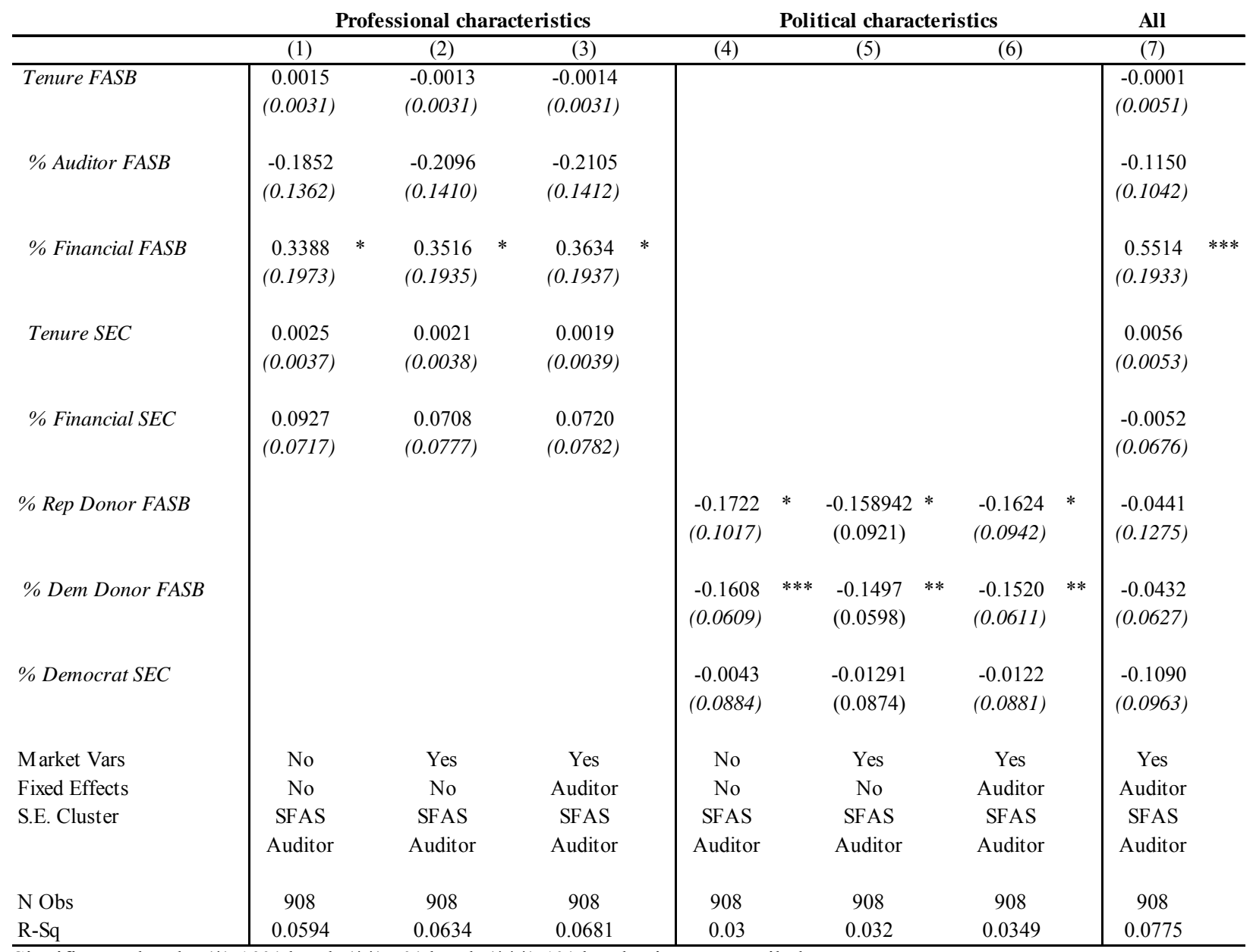

Significance levels: $\left(^{*}\right) 10 \%$ level, $(* *) 5 \%$ level, $(* * *) 1 \%$ level using a two-tailed t-test. 


\section{Table 6A \\ Differences in means of explanatory variables across the comment-letter and manually assessed sub-samples}

Two-sample differences-in-means t-tests are performed on pairs of three distinct sub-samples. Sub-sample A is the 126 exposure drafts for which we have both manual assessments and auditor comment letters. Sub-sample B is the 19 exposure drafts for which we have manual assessments but no auditor comment letters. Sub-sample C is the 23 exposure drafts for which we have auditor comment letters but no manual assessments. Tenure FASB is an ED-level measure of the average tenure in years of all extant FASB members. \% Auditor FASB is an ED-level measure of the proportion of extant FASB members with most recent former employ in auditing. \% Financial FASB is an ED-level measure of the proportion of extant FASB members with most recent former employ in investment banking/ investment management. \%Rep Donor FASB is an ED-level measure of the proportion of extant FASB members making campaign contributions to the Republican Party or candidates. \% Dem Donor FASB is an ED-level measure of the proportion of extant FASB members making campaign contributions to the Democratic Party or candidates. Tenure SEC is an ED-level measure of the average tenure in years of all extant SEC commissioners. \% Financial $S E C$ is an ED-level measure of the proportion of extant SEC commissioners with most recent former employ in financial services. \% Democrat SEC is an ED-level measure of the proportion of extant Democratic SEC commissioners.

\begin{tabular}{|c|c|c|c|c|c|c|}
\hline & A & $A \& B$ & B & $B \& C$ & C & $C \& A$ \\
\hline Tenure FASB & 4.335 & & 4.277 & $* * *$ & 2.907 & $* * *$ \\
\hline$\%$ Auditor FASB & 0.389 & & 0.396 & & 0.419 & $* * *$ \\
\hline$\%$ Financial FASB & 0.064 & & 0.038 & * & 0.000 & $* * *$ \\
\hline Tenure SEC & 3.018 & & 3.028 & & 2.427 & $* *$ \\
\hline$\%$ Financial SEC & 0.188 & & 0.137 & & 0.076 & \\
\hline$\%$ Rep Donor FASB & 0.191 & & 0.173 & $* *$ & 0.087 & $* * *$ \\
\hline$\%$ Dem Donor FASB & 0.126 & & 0.140 & $* * *$ & 0.405 & $* * *$ \\
\hline$\%$ Democrat $S E C$ & 0.453 & & 0.464 & & 0.389 & $* *$ \\
\hline \# of exposure drafts & 126 & & 19 & & 23 & \\
\hline Big $\mathrm{N}$ auditor comment letters available & Yes & & No & & Yes & \\
\hline Manual assessments available & Yes & & Yes & & No & \\
\hline
\end{tabular}

Significance levels: $(*) 10 \%$ level, $(* *) 5 \%$ level, $(* * *) 1 \%$ level using a two-tailed t-test. 


\section{Table 6B}

\section{OLS regression of Manual_dec_relb and Manual_inc_relv on the characteristics of FASB members and SEC commissioners}

Sample is the 126 exposure drafts for which we have both auditor comment letters and manual assessments (See Table 9A). Manual_inc_relv is an assessment that a proposed SFAS will increase "relevance" as determined by two independent reviewers. Manual_dec_relb is an assessment that a proposed SFAS will decrease "reliability" as determined by two independent reviewers. See Section 3 for details. Tenure FASB is an ED-level measure of the average tenure in years of all extant FASB members. \% Auditor FASB is an ED-level measure of the proportion of extant FASB members with most recent former employ in auditing. \% Financial FASB is an ED-level measure of the proportion of extant FASB members with most recent former employ in investment banking/ investment management. \%Rep Donor FASB is an ED-level measure of the proportion of extant FASB members making campaign contributions to the Republican Party or candidates. \% Dem Donor FASB is an ED-level measure of the proportion of extant FASB members making campaign contributions to the Democratic Party or candidates. Tenure SEC is an ED-level measure of the average tenure in years of all extant SEC commissioners. \% Financial SEC is an ED-level measure of the proportion of extant SEC commissioners with most recent former employ in financial services. \% Democrat SEC is an ED-level measure of the proportion of extant Democratic SEC commissioners. The market variables are VWRETD and sd_VWRETD. VWRETD is the annual value-weighted market return (from CRSP) for the 12 months directly preceding the month in which a proposed SFAS was issued. sd_VWRETD is the standard deviation of daily VWRETD for the 12 months directly preceding the month in which a proposed SFAS was issued. Figures in italics and parentheses are standard errors.

\begin{tabular}{|c|c|c|c|c|c|c|c|}
\hline & \multicolumn{3}{|c|}{ Manual_dec_relb } & \multicolumn{4}{|c|}{ Manual_inc_relv } \\
\hline & (1) & (2) & (3) & (4) & (5) & (6) & \\
\hline \multirow[t]{2}{*}{ Tenure FASB } & 0.0313 & & 0.0551 & 0.0015 & & 0.0302 & \\
\hline & $(0.0352)$ & & $(0.0448)$ & $(0.0943)$ & & (0.1241) & \\
\hline \multirow[t]{2}{*}{$\%$ Auditor FASB } & -0.8485 & & -0.2959 & -2.1387 & & -1.6739 & \\
\hline & $(0.5551)$ & & $(0.7059)$ & $(1.4911)$ & & (1.8935) & \\
\hline \multirow[t]{2}{*}{ \% Financial FASB } & $1.3714 * *$ & & $1.9236 \quad * * *$ & 5.8551 & $* * *$ & 8.7955 & $* * *$ \\
\hline & $(0.5541)$ & & $(0.6928)$ & $(1.6954)$ & & $(1.9482)$ & \\
\hline \multirow[t]{2}{*}{ Tenure SEC } & 0.0250 & & 0.0588 & 0.0467 & & 0.1058 & \\
\hline & $(0.0419)$ & & $(0.0495)$ & $(0.1008)$ & & $(0.1292)$ & \\
\hline \multirow[t]{2}{*}{ \% Financial SEC } & 0.2801 & & 0.0261 & 0.8158 & & -0.3722 & \\
\hline & $(0.3030)$ & & $(0.3493)$ & $(0.8384)$ & & $(0.9230)$ & \\
\hline \multirow[t]{2}{*}{$\%$ Rep Donor FASB } & & $-0.7617 *$ & -0.7157 & & $-2.3263 * * *$ & -0.2012 & \\
\hline & & $(0.4181)$ & $(0.5874)$ & & $(0.8732)$ & $(1.3590)$ & \\
\hline \multirow[t]{2}{*}{ \% Dem Donor FASB } & & $-0.6918 * *$ & -0.1197 & & -1.2018 & 0.8250 & \\
\hline & & $(0.3165)$ & $(0.3951)$ & & $(1.0331)$ & (1.3185) & \\
\hline \multirow[t]{2}{*}{$\%$ Democrat SEC } & & 0.0833 & -0.2491 & & -0.0319 & -1.8942 & $* * *$ \\
\hline & & $(0.2231)$ & $(0.2971)$ & & $(0.5728)$ & $(0.6855)$ & \\
\hline Market Vars & Yes & Yes & Yes & Yes & Yes & Yes & \\
\hline Fixed Effects & No & No & No & No & No & No & \\
\hline S.E. & Robust & Robust & Robust & Robust & Robust & Robust & \\
\hline N Obs & 126 & 126 & 126 & 126 & 126 & 126 & \\
\hline $\mathrm{R}-\mathrm{Sq}$ & 0.1253 & 0.0717 & 0.1482 & 0.2771 & 0.0696 & 0.3294 & \\
\hline
\end{tabular}

Significance levels: $(*) 10 \%$ level, $(* *) 5 \%$ level, $(* * *) 1 \%$ level using a two-tailed t-test. 